\title{
Effect of the flavonoids quercetin and taxifolin on UVA-induced damage to human primary skin keratinocytes and fibroblasts
}

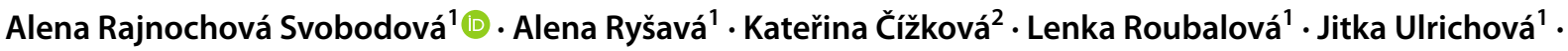 \\ Jiří Vrba ${ }^{1} \cdot$ Bohumil Zálešák $^{3} \cdot$ Jitka Vostálová $^{1}$ [i]
}

Received: 11 August 2021 / Accepted: 10 November 2021 / Published online: 27 November 2021

( ) The Author(s), under exclusive licence to European Photochemistry Association, European Society for Photobiology 2021

\begin{abstract}
The ultraviolet (UV) part of solar radiation can permanently affect skin tissue. UVA photons represent the most abundant UV component and stimulate the formation of intracellular reactive oxygen species (ROS), leading to oxidative damage to various biomolecules. Several plant-derived polyphenols are known as effective photoprotective agents. This study evaluated the potential of quercetin $(\mathrm{QE})$ and its structurally related flavonoid taxifolin (TA) to reduce UVA-caused damage to human primary dermal fibroblasts (NHDF) and epidermal keratinocytes (NHEK) obtained from identical donors. Cells pre-treated with QE or TA $(1 \mathrm{~h})$ were then exposed to UVA light using a solar simulator. Both flavonoids effectively prevented oxidative damage, such as ROS generation, glutathione depletion, single-strand breaks formation and caspase-3 activation in NHDF. These protective effects were accompanied by stimulation of $\mathrm{Nrf} 2$ nuclear translocation, found in non-irradiated and irradiated NHDF and NHEK, and expression of antioxidant proteins, such as heme oxygenase-1, NAD(P)H:quinone oxidoreductase 1 and catalase. For most parameters, QE was more potent than TA. On the other hand, TA demonstrated protection within the whole concentration range, while $\mathrm{QE}$ lost its protective ability at the highest concentration tested $(75 \mu \mathrm{M})$, suggesting its pro-oxidative potential. In summary, QE and TA demonstrated UVA-protective properties in NHEK and NHDF obtained from identical donors. However, due to the in vitro phototoxic potential of $\mathrm{QE}$, published elsewhere and discussed herein, further studies are needed to evaluate QE safety in dermatological application for humans as well as to confirm our results on human skin ex vivo and in clinical trials.
\end{abstract}

\section{Graphical abstract}

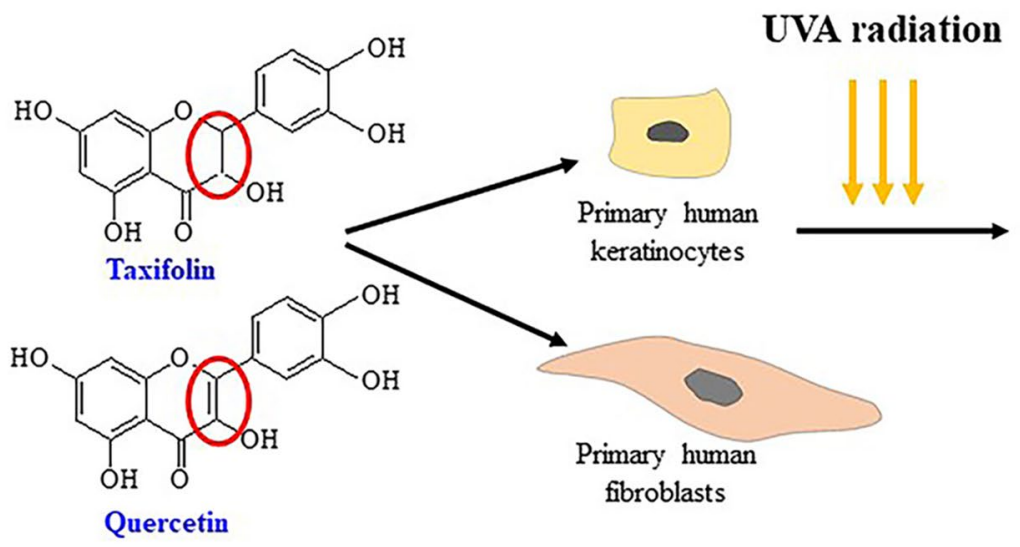

Reduction of:

- ROS generation

- GSH depletion

- Single strand breaks formation

- Caspase- 3 activation

Increase of:

- Nrf2 nuclear translocation

- HO-1 mRNA and/or protein level

- NQO1 mRNA and/or protein level

- Catalase protein level

Keywords UVA radiation · Oxidative stress · Flavonoids · Nuclear factor Nrf2 $\cdot$ Human skin fibroblasts · Human skin keratinocytes

Jitka Vostálová

j.psotova@email.cz; jitka.vostalova@upol.cz

Extended author information available on the last page of the article 


\section{Introduction}

The sunlight to which human skin is normally exposed includes exclusively wavelengths greater than $290 \mathrm{~nm}$. A small but biologically very significant amount $(\sim 5 \%)$ of solar radiation represents ultraviolet (UV) light. More than $90 \%$ of solar UV radiation reaching the Earth's surface falls within the 320-400 nm (UVA) wavelength range. The main cause of UVA-induced damage can be attributed to the overproduction of intracellular reactive oxygen species (ROS). These are generated by the direct excitation of endogenous chromophore molecules including $\mathrm{NAD}(\mathrm{P}) \mathrm{H}$, tryptophan, porphyrins, melanin [1]. UVA photons penetrate deep into the skin and, thus, the generated ROS affect both dermal and epidermal skin structures. ROS can interact with intracellular macromolecules leading to lipid peroxidation, protein oxidation and DNA base modifications. Unstable oxidised products cause alteration to various cellular signalling pathways. One of the affected pathways is that driven by the nuclear factor erythroid-2 related factor 2 (Nrf2). This transcriptional factor has a crucial role in skin protection against oxidative damage and controls expression of genes responsible for several antioxidants, detoxication and cytoprotective proteins including $\mathrm{NAD}(\mathrm{P}) \mathrm{H}$ :quinone oxidoreductase 1 (NQO1) and heme oxygenase-1 (HO-1) [2]. However, intensive exposure to UVA light can overwhelm these protective mechanisms, and chronic exposure to UVA radiation leads to the stepby-step accumulation of oxidatively modified molecules that may result in skin inflammation, immunosuppression, photodermatosis, photoageing and/or carcinogenesis.

Natural compounds have attracted significant attention for their potential use in dermal preparation as there is an increasing trend to substitute synthetic chemicals with natural molecules. In sunscreen products, there has also been an effort to reduce the quantity of synthetic sunscreen agents present in cosmetic formulations, as some of the currently used compounds have shown (photo)instability and associated harmful effects [3]. A wide range of naturally occurring phytochemicals, namely, polyphenols, have been studied for their ability to prevent the deleterious effects of UVA on human skin [4]. One of the most abundant polyphenolic compounds in nature is quercetin $\left(3,5,7,3^{\prime}, 4^{\prime}\right.$-pentahydroxyflavone, QE). This flavonoid is present in various common fruits, vegetables and beverages, where it is mostly found in the form of quercetin glycosides. Numerous biological effects of QE have been published in a great number of in vitro and in vivo studies. Specifically, QE exhibits antioxidant, anti-inflammatory, immunoprotective, chemopreventive and anti-carcinogenic effects [5]. Currently, QE in its free form (aglycone) is largely utilized as a nutritional supplement and as a phytochemical remedy for a variety of diseases, such as diabetes, obesity, cardiovascular diseases, asthma, viral infections, mood disorders and cancer prevention [5,6]. Due to its antioxidant and anti-inflammatory activity, QE is also used as an active component in cosmetic preparations, as a pure compound or as a plant extract (mixed with other polyphenols). Results from several studies have shown the protective effects of QE against UVB [7-10] as well as UVA radiation [11-15], suggesting the possibility of using QE in photoprotective preparations. However, various in vitro studies have indicated toxic effects associated with QE, most probably linked to its pro-oxidant potential, which may exceed its protective ability, at least under some circumstances [6]. Moreover, both UVA and UVB light were found to induce QE degradation [16].

This study hence aimed to evaluate the potential of $\mathrm{QE}$ pre-treatment to reduce UVA-induced damage to human primary dermal fibroblasts (NHDF) and epidermal keratinocytes (NHEK) obtained from a single donor. A structurally related flavonoid, taxifolin (dihydroquercetin, TA), was included in the experiments to better understand the structure-activity relationship (see Fig. 1).

\section{Materials and methods}

\subsection{Chemicals}

Keratinocyte basal medium-2 (KBM-2), KBM-2 supplements kit KGM ${ }^{\mathrm{TM}}-2$ SingleQuots ${ }^{\mathrm{TM}}$, EpiLife ${ }^{\circledR}$ medium, human keratinocyte growth supplement kit and heat-inactivated fetal bovine serum (FBS, HyCylone ${ }^{\mathrm{TM}}$ ) were from Life Technologies (Czech Republic). Ammonium peroxodisulfate

Fig. 1 Chemical structures of the studied flavonoids<smiles>O=C1c2c(O)cc(O)cc2OC(c2ccc(O)c(O)c2)C1O</smiles>

Taxifolin (TA)<smiles>O=c1c(O)c(-c2ccc(O)c(O)c2)oc2cc(O)cc(O)c12</smiles>

Quercetin (QE) 
was from BioChemika Fluka (Czech Republic). Complete ${ }^{\mathrm{TM}}$ Protease inhibitor cocktail tablets and Sybr Green were from Roche Diagnostics (Germany). The Pierce ${ }^{\mathrm{TM}}$ BCA protein assay kit was from Thermo Fisher Scientific (Czech Republic). Albumin bovine fraction $\mathrm{V}$ (BSA) and agarose for DNA electrophoresis was from Serva (Germany). Non-fat milk was purchased from Samantha (Czech Republic). Western blotting luminol reagent (ImmunoCruz ${ }^{\mathrm{TM}}$ ) for chemiluminescent horseradish peroxidase (HRP) detection, $\mathrm{Nrf} 2$ rabbit polyclonal IgG (C-20, sc-722), heme oxygenase 1 (HO-1) rabbit polyclonal IgG (H-105, sc-10789), NQO1 goat polyclonal IgG (R-20, sc-16463), catalase (CAT) rabbit polyclonal IgG (sc-50508), caspase-3 rabbit polyclonal IgG (for detection of pro-caspase-3 and caspase-3), actin goat polyclonal IgG (I-19, sc-1616), goat anti-rabbit and rabbit antigoat HRP-conjugated secondary antibody were purchased from Santa Cruz Biotechnology Inc. (USA). Solution 1 for primary antibodies and Solution 2 for secondary antibodies were from Calbiochem (USA). Acrylamide-bis-acrylamide mixture (29:1)) was from Merck (Czech Republic). TRI Reagent ${ }^{\circledR}$ solution, High-capacity cDNA reverse transcription kit, TaqMan universal PCR master mix and TaqMan gene expression assays, consisting of the specific primers Hs01110250_m1 for HO-1, Hs02512143_s1 for NQO1 and Hs99999905_m1 for glyceraldehyde 3-phosphate dehydrogenase (GAPDH), FAM dye-labelled TaqMan minor groove binder probes were from Applied Biosystems (USA). Protein block serum-free, peroxidase and diaminobenzidine (DAB), Dako REAL ${ }^{\mathrm{TM}}$ antibody diluent, secondary antibody DAKO REAL EnVision ${ }^{\mathrm{TM}}$ HRP Mouse/Rabbit were from DAKO (Denmark). Dulbecco's modified Eagle's medium (DMEM), Ham's F12 nutrient mixture, stabilised penicillin-streptomycin solution, amphotericin B, hydrocortisone, adenine, insulin, epidermal growth factor, 3,3',5-triiod-L-thyronin, ampicillin, trypsin-EDTA (0.25\%), neutral red (NR), Ponceau $\mathrm{S}$ in acetic acid $(0.1 \%$; (w/v)), sodium dodecyl sulphate (SDS), N,N,N',N'-tetramethylethylenediamine (TEMED), Carestream ${ }^{\circledR}$ BioMax ${ }^{\circledR}$ light film, Carestream ${ }^{\circledR}$ autoradiography GBX fixer/replenisher, dichlorodihydrofluorescein diacetate, 2,2'-dinitro-5,5'-dithiobenzoic acid (DTNB), quercetin $(\mathrm{QE})$, taxifolin (TA), sulphoraphane (SFN) and other chemicals were from Sigma-Aldrich (Czech Republic).

\subsection{Cell culture}

Primary skin cells (NHDF and NHEK) were isolated from superfluous skin from healthy adult donors. The tissue specimens were obtained from patients undergoing plastic surgery at the Department of Plastic and Aesthetic Surgery (University Hospital Olomouc). The tissue acquisition protocol adhered to the requirements of the Ethics Committee of University Hospital Olomouc and the Faculty of Medicine and Dentistry, Palacký University, Olomouc (ref. number 41/09). All volunteers signed their written informed consent.

For NHEK and NHDF isolation, identical donors were used. Before use, the skin fragments were washed three times in phosphate buffered saline (PBS) containing antibiotics (penicillin $(500 \mathrm{mg} / \mathrm{ml})$, streptomycin $(500 \mathrm{U} / \mathrm{ml})$ and amphotericin $B(1.25 \mathrm{mg} / \mathrm{ml}))$. NHEK were isolated according to protocol of Minner et al. [17] with some modifications [18]. NHEK were cultured in EpiLife ${ }^{\circledR}$ medium supplemented with human keratinocyte growth supplement kit, penicillin $(100 \mathrm{mg} / \mathrm{ml})$, streptomycin $(100 \mathrm{mg} / \mathrm{l})$ and ampicillin $(250 \mu \mathrm{g} / \mathrm{ml})$ in a humidified atmosphere with $\mathrm{CO}_{2}$ $\left(5 \%\right.$; v/v) at $37^{\circ} \mathrm{C}$. For the experiments, keratinocytes were used at the 3th passage. NDHF were obtained as described previously [19]. The cells were grown in DMEM supplemented with FBS (10\%; v/v), penicillin $(100 \mathrm{mg} / \mathrm{ml})$ and streptomycin $(100 \mathrm{U} / \mathrm{ml})$ in a humidified atmosphere with $\mathrm{CO}_{2}\left(5 \%\right.$; v/v) at $37^{\circ} \mathrm{C}$. For the experiments, fibroblasts were used between the 2nd and 4th passage.

For the experiments, NHEK were seeded in corresponding medium on cell culture plastics (TPP ${ }^{\circledR}$, Biotech, Czech Republic) and NHDF were seeded in corresponding medium on collagen-coated cell culture plastics (TPP ${ }^{\circledR}$, Biotech, Czech Republic) at the required cell concentration $/ \mathrm{cm}^{2}$.

For immunocytochemical analysis, cells were seeded in a drop of appropriate medium $(100 \mu \mathrm{l})$ on sterile SuperFrost ${ }^{\circledR}$ Plus Menzel-Glaser slides (Thermo Scientific, Czech Republic). The optimal amount for NHEK was $\sim 1 \times 10^{4}$ cells/drop and $\sim 5 \times 10^{3}$ cells/drop for NHDF. The slides were placed in a humid chamber for cell adhesion (NHDF 3 h, NHEK $24 \mathrm{~h}$ ), fresh medium was then applied, and cells were incubated overnight.

\subsection{Cytotoxicity of test compounds}

To evaluate the cytotoxic potential of $\mathrm{QE}$ and TA, the flavonoids were tested in a range of 1.56-100 $\mu \mathrm{M}$. NHDF/NHEK on 96-well plates were treated with flavonoids in serum-free medium for $24 \mathrm{~h}$. Compounds were dissolved in DMSO so that the final concentration of DMSO in the medium was $0.5 \%(\mathrm{v} / \mathrm{v})$. Control cells were treated with the medium containing DMSO $(0.5 \%, \mathrm{v} / \mathrm{v})$ under the same conditions. After the experiment, cell viability was then evaluated by the incorporation of neutral red (NR). Retained NR was measured spectrophotometrically as described previously [20].

\subsection{Photoprotection potential of test compounds}

Skin cells were pre-treated with QE or TA in corresponding serum-free medium for $1 \mathrm{~h}$. For GSH and ROS evaluation, only NHDF were used and a wide range of flavonoid concentrations $(6.25,12.5,25$ and $75 \mu \mathrm{M})$ was tested. For more specific markers, evaluated by comet assay, 
immunocytochemistry, Western blot and PCR analysis, both NHDF and NHEK were used and the effect of QE and TA was tested at two lower concentrations (6.25 and $12.5 \mu \mathrm{M})$ for their significance for potential practical use. SFN $(6.25 \mu \mathrm{M})$ was used as a positive control.

After incubation with the flavonoids, cells were washed twice with PBS and then PBS supplemented with glucose $(1 \mathrm{mg} / \mathrm{ml})$ was applied. Cells (+ UVA) were exposed to UVA radiation (doses are specified below) on ice-cold plates to eliminate UV-induced thermal stimulation. A solar simulator, SOL 500 (Dr. Hönle UV Technology, Germany), with a spectral range (295-3000 nm) corresponding to natural sunlight was used for irradiation. The simulator was equipped with a H1 filter transmitting wavelengths of 315-380 $\mathrm{nm}$. The UVA output before each experiment was measured with a UVA meter (Dr. Hönle UV Technology, Germany). The UVA doses used were chosen according to our previous experiments (data not shown) [20, 21]. In parallel, non-irradiated cells (- UVA) were treated similarly and kept in the dark. After irradiation, corresponding serum-free medium was applied and cells were incubated for 1-24 $\mathrm{h}$ according to the measured parameter. Optimal incubation times for individual parameters were chosen according to previous studies [20,21].

\subsection{Level of ROS and GSH}

The effect of flavonoids and UVA radiation $\left(10 \mathrm{~J} / \mathrm{cm}^{2}\right)$ on ROS and GSH levels in fibroblasts was measured 1 and $4 \mathrm{~h}$ after UVA exposure, respectively. ROS level was measured by dichlorodihydrofluorescein diacetate assay, GSH level using the reaction with 2,2'-dinitro-5,5'-dithiobenzoic acid (DTNB) as described previously [20].

\subsection{DNA single-strand breaks}

An alkaline comet assay was used to evaluate the amount of DNA single-strand breaks (SSBs). The cells were harvested $4 \mathrm{~h}$ after UVA exposure $\left(10 \mathrm{~J} / \mathrm{cm}^{2}\right.$ for NHDF, $15 \mathrm{~J} / \mathrm{cm}^{2}$ for NHEK) and processed as described previously [20]. An Axiovert 40 CFL inversion fluorescent microscope (ZEISS, Germany) was used for nuclei analysis and the fluorescent stain Sybr Green was used to visualise DNA. The damage was assessed in 100 nuclei per slide area by visual scoring from 0 (undamaged, no discernible comet tail) to 4 (almost all DNA in tail, insignificant head). Each comet was given a value according to its classification to produce an overall score for each slide ranging from 0 to 400 arbitrary units. Scores were calculated using the following formula:

Total damage $(\%)=\frac{N_{0} \cdot 0+N_{1} \cdot 1+N_{2} \cdot 2+N_{3} \cdot 3+N_{4} \cdot 4}{N_{0}+N_{1}+N_{2}+3 N_{4}} \cdot 100$,

$\mathrm{N} 0, \mathrm{~N} 1, \mathrm{~N} 2, \mathrm{~N} 3$, and $\mathrm{N} 4$... number of cells in each group from 0 to 4 .

\subsection{Western blot analysis}

After irradiation $\left(7.5 \mathrm{~J} / \mathrm{cm}^{2}\right.$ for NHDF, $10 \mathrm{~J} / \mathrm{cm}^{2}$ for NHEK) and incubation ( $24 \mathrm{~h}$ for NHDF, $6 \mathrm{~h}$ for NHEK), cells were scraped into a medium and centrifuged (10 $\mathrm{min}, 1200 \mathrm{rpm}$, $\left.22{ }^{\circ} \mathrm{C}\right)$. The medium was removed, pellets were then resuspended in cold PBS and cells were centrifuged (10 min, $1200 \mathrm{rpm}, 4{ }^{\circ} \mathrm{C}$ ). Total cellular lysates were prepared as described by Zdařilová et al. The amount of proteins in the samples was quantified using the bicinchoninic acid (BCA) assay. All lysates were stored at $-80^{\circ} \mathrm{C}$.

Proteins were separated in $12.5 \%$ SDS-polyacrylamide gel and transferred onto polyvinylidine difluoride membrane (Immobilon ${ }^{\circledR}$-P, Merck). Membranes were blocked with non-fat milk or BSA $(5 \%$, w/v) in Tris-buffered saline (100 mM Tris, $\mathrm{NaCl}(0.9 \%, \mathrm{w} / \mathrm{v})$, Tween-20 (0.05\%, v/v); $\mathrm{pH} 7.5$; TBS/T) for $2 \mathrm{~h}$ and then incubated with specific primary human antibodies (overnight, $\left.4{ }^{\circ} \mathrm{C}\right)$ : Nrf2 (1:500, in Solution 1 for primary antibodies), HO-1 (1:500, in BSA $(5 \%, \mathrm{w} / \mathrm{v})$ in TBS/T), NQO1 (1:500, in Solution 1 for primary antibodies), caspase-3 (1:500, in BSA $(5 \%, w / v)$ in TBS/T), CAT (1:500, in BSA (5\%, w/v) in TBS/T) and actin (1:500, in non-fat milk (5\%, w/v) in TBS/T). Membranes were then washed in TBS/T and treated with HRP-conjugated secondary antibody for $1 \mathrm{~h}$ : goat anti-rabbit or rabbit anti-goat (1:5000) in Solution 2 for secondary antibodies or in non-fat milk $(5 \%, \mathrm{w} / \mathrm{v})$ in TBS/T or in BSA $(5 \%, \mathrm{w} / \mathrm{v})$ in TBS/T. After washing in TBS/T, proteins were detected by chemiluminescence and autoradiography. Quantification of the proteins was performed by a dosimetric analysis using the image processing software ImageJ (http://imagej.nih. gov/ij/ provided in the public domain by the National Institutes of Health, Bethesda, MD, USA). The proteins were normalised to a reference protein actin.

\subsection{Quantitative real-time PCR analysis}

After irradiation ( $7.5 \mathrm{~J} / \mathrm{cm}^{2}$ for NHDF, $10 \mathrm{~J} / \mathrm{cm}^{2}$ for NHEK) and incubation ( $24 \mathrm{~h}$ for NHDF, $6 \mathrm{~h}$ for NHEK), the total RNA was extracted from cells as per the manufacturer's instructions, using $1 \mathrm{ml}$ of TRI Reagent ${ }^{\circledR}$ solution. The concentration of extracted RNA was determined by spectrophotometry at $260 \mathrm{~nm}$ using a Pearl nanophotometer (Implen, Germany), and RNA purity was estimated according to the ratio between the absorbance values at 260 and $280 \mathrm{~nm}$. For all samples, the A260/A280 ratio was higher than 1.9. RNA samples $(2 \mu \mathrm{g})$ were reverse-transcribed using a High-capacity cDNA reverse transcription kit as per the manufacturer's recommendations. Real-time PCR analysis was performed in a LightCycler 480 II system (Roche Diagnostics, Germany) using TaqMan universal PCR master mix and TaqMan gene expression assays, consisting of specific primers (for HO-1 and NQO1) and FAM dye-labelled TaqMan minor groove 
binder probes. The assay ID is specified in the Chemicals section. Amplification conditions were $50{ }^{\circ} \mathrm{C}$ for $2 \mathrm{~min}$, $95{ }^{\circ} \mathrm{C}$ for $10 \mathrm{~min}$, followed by 40 cycles at $95^{\circ} \mathrm{C}$ for $15 \mathrm{~s}$ and $60^{\circ} \mathrm{C}$ for $1 \mathrm{~min}$. Crossing point values, equivalent to $C_{\mathrm{T}}$, were determined using second derivative maximum analysis. Relative changes in gene expression were calculated by the comparative $C_{\mathrm{T}}$ method using the $2^{-\Delta \Delta C_{\mathrm{T}}}$ equation [22]. The results were normalized to GAPDH mRNA levels, which did not vary with time and in response to UVA irradiation.

\subsection{Immunocytochemical analysis}

After compound and UVA treatment $\left(7.5 \mathrm{~J} / \mathrm{cm}^{2}\right.$ for NHDF, $10 \mathrm{~J} / \mathrm{cm}^{2}$ for NHEK) and incubation ( $3 \mathrm{~h}$ for NHDF, $6 \mathrm{~h}$ for NHEK) cells on slides were washed in PBS, fixed in cold methanol-acetone mixture $(1: 1 ; 15 \mathrm{~min})$, air-dried and stored at $-20^{\circ} \mathrm{C}$. To detect Nrf2 protein, cells were first rehydrated in tap water $(5 \mathrm{~min})$ and heat-induced antigen retrieval in citric buffer ( $10 \mathrm{mM}$ citric acid, $10 \mathrm{mM}$ sodium citrate, $\mathrm{pH}$ 6) was performed (Histos, Milestone, $120^{\circ} \mathrm{C}, 15 \mathrm{~min}$ ). The slides were then incubated in hydrogen peroxide $(0.3 \%, \mathrm{v} / \mathrm{v}$, $15 \mathrm{~min}$, room temperature) and in protein block serum-free (10 min, room temperature). In the next step, cells were incubated with Nrf2 rabbit polyclonal IgG primary antibody (1:50) in Dako REAL ${ }^{\mathrm{TM}}$ antibody diluent overnight at $4{ }^{\circ} \mathrm{C}$. Protein detection was performed using a rabbit/mouse secondary antibody and peroxidase/DAB substrate. Tris buffered saline (50 mM Tris, $\mathrm{pH}$ 7.6) was used for washing steps. The nuclei of all samples were counterstained with haematoxylin. Finally, the samples were then dehydrated and cover-slipped. In the negative control samples, the primary antibody was substituted with Tris-buffered saline.

The intensity of Nrf2 immunostaining was evaluated semi-quantitatively by dividing it into a scale of four categories as: negative $\left(\mathrm{C}_{1}\right)$, weak positive $\left(\mathrm{C}_{2}\right)$, moderate positive $\left(\mathrm{C}_{3}\right)$ and strong positive $\left(\mathrm{C}_{4}\right)$. The nucleus and cytoplasm were evaluated separately in six fields of vision at magnification $200 \times$ captured by an Olympus BX40 light microscope equipped with an Olympus DP71 camera. Cells were counted using QuPath v 0.2.0 software. The overall Nrf2 immunostaining was evaluated by the histoscore according to the following formula: statistical comparison was performed using Student's $t$ test. Statistical significance was determined at $p<0.05$.

\section{Results}

\subsection{Effect of flavonoids on cell viability}

A possible adverse effect of flavonoids on viability was assessed in a broad concentration range of $1.6-100 \mu \mathrm{M}$ after $24 \mathrm{~h}$ treatment. As QE is a strong antioxidant, the NR assay was preferred instead of the frequently used MMT assay, as it may be affected by the compound's antioxidant properties. Both flavonoids themselves caused minimal morphological changes in cells that were observed microscopically. TA demonstrated no alteration to NHDF and NHEK cell viability $24 \mathrm{~h}$ after application (Fig. 2). In fibroblasts treated with QE, retention of NR was decreased at concentrations of 75 and $100 \mu \mathrm{M}$. However, the reduction was only non-significant to 95 and $88 \%$ of control cells, respectively (Fig. 2A). NHEK were more sensitive to QE treatment as NR retention was reduced at QE concentrations of $50-100 \mu \mathrm{M}(78-55 \%$ of control). On the other hand, QE significantly enhanced the viability at 6.25 and $12.5 \mu \mathrm{M}$ to $128 \%$ of control cells (Fig. 2B).

\subsection{Effect of flavonoids on ROS and GSH level in UVA-treated fibroblasts}

The effect of flavonoids on ROS and GSH level was evaluated up to a concentration of $75 \mu \mathrm{M}$ to reach prospective phototoxic effect that has been described for QE [23]. UVA radiation stimulated ROS generation in NHDF only $1 \mathrm{~h}$ after exposure ( $150 \%$ of non-irradiated cells). Pre-treatment with QE $(6.25-25 \mu \mathrm{M})$ resulted in a significant concentration-dependent reduction in ROS level (Fig. 3). The protection was nearly $66 \%$ at the lowest concentration $(6.25 \mu \mathrm{M})$ and nearly $95 \%$ at a concentration of $25 \mu \mathrm{M}$. At the highest QE concentration $(75 \mu \mathrm{M})$, however, the protection dropped to only $34 \%$. In cells pre-treated with TA, a concentrationdependent protective effect was found with a maximum of $74 \%$ for the highest concentration $(75 \mu \mathrm{M})$.

Histoscore $=\left[\left(0^{\bullet} \%\right.\right.$ of $\left.\mathrm{C}_{1}\right)+\left(1^{\bullet} \%\right.$ of $\left.\mathrm{C}_{2}\right)+\left(2^{\bullet} \%\right.$ of $\left.\mathrm{C}_{3}\right)+\left(3^{\bullet} \%\right.$ of $\left.\left.\mathrm{C}_{4}\right)\right]$

The overall score for each sample can range from 0 to 300 arbitrary units.

\subsection{Statistical analysis}

The data were processed in MS Excel and presented as means \pm SD of at least three independent experiments. The
Exposure of NHDF to UVA radiation resulted in a significant depletion of intracellular GSH level. Pre-treatment with QE reduced the GSH depletion. The protective effect was maximal at concentrations of 12.5 and $25 \mu \mathrm{M}(90 \%)$ and then decreased at a concentration of $75 \mu \mathrm{M}(38 \%)$. TA demonstrated a significant concentration-dependent elevation in GSH level in irradiated cells (48\% for the lowest 
Fig. 2 Effect of flavonoids on skin cell viability. NHDF and NHEK were treated with TA and QE (six replicate wells per concentration) for $24 \mathrm{~h}$ and then viability was evaluated by NR assay. Results are mean $\pm \mathrm{SD}$ of 3 experiments employing cells from 3 donors

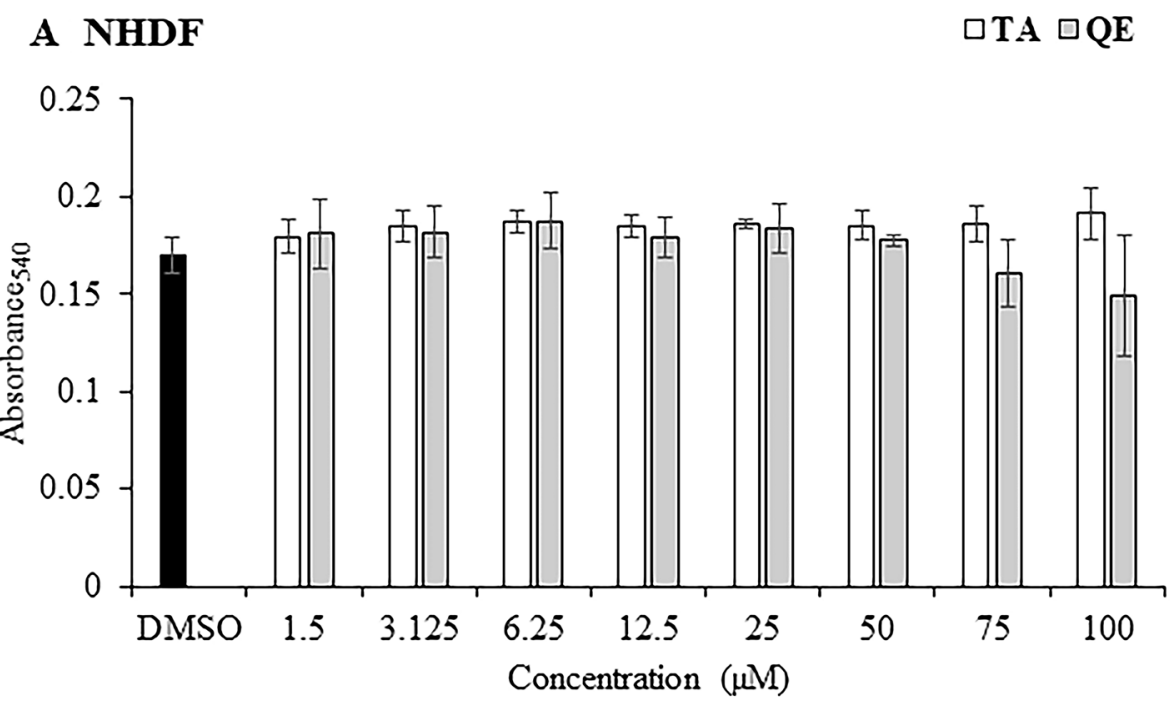

B NHEK

$\square \mathrm{TA} \square \mathrm{QE}$

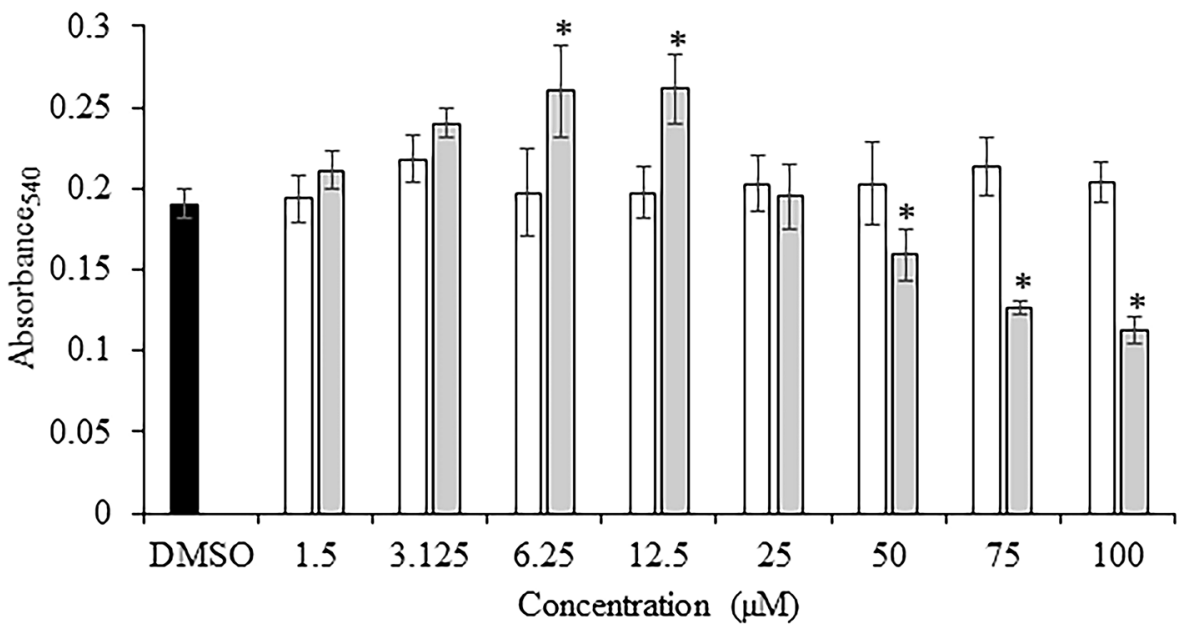

concentration and nearly $78 \%$ for the highest one) (Fig. 4). In addition to the photoprotective effect, $\mathrm{QE}$ treatment also dose-dependently increased the basal level of GSH in nonirradiated cells. However, this increase was not significant. Such GSH basal level enhancement was not observed in cells treated with TA (Fig. 4).

\subsection{Effect of flavonoids on caspase-3 activation in UVA-treated fibroblasts}

Exposure of NHDF to UVA light resulted in a significant activation of caspase-3 (cleavage to pro-caspase-3 to its active form). Pre-treatment of fibroblasts with flavonoids decreased the active caspase- 3 level. Their effect was comparable and concentration dependent (Fig. 5).

\subsection{Effect of flavonoids on DNA damage in UVA-treated skin cells}

UVA radiation also caused a significant increase in DNA damage, detected as SSBs formation in both NHDF and NHEK. The damage was higher in keratinocytes $(165 \pm 26$ vs. control $30.2 \pm 1.6)$ than in fibroblasts $(106 \pm 38$ vs. control $28.6 \pm 15.9)$. Pre-treatment with flavonoids $(6.25$ and $12.5 \mu \mathrm{M})$ significantly reduced total DNA damage in both cells and their effect was comparable (Fig. 6).

\subsection{Effect of flavonoids and UVA on Nrf2 nuclear translocation in skin cells}

The potential of TA and QE to influence UVA-induced modulation of Nrf2 nuclear translocation and expression 
Fig. 3 Effect of flavonoids on UVA-induced ROS generation in NHDF. Fibroblasts pretreated with TA and QE $(1 \mathrm{~h})$ were non-irradiated (- UVA) or exposed to $10 \mathrm{~J} / \mathrm{cm}^{2}$ (+ UVA) and after incubation ( $1 \mathrm{~h})$, ROS level was evaluated as described in Materials and Methods. Results are mean \pm SD of 4 experiments employing cells from 4 donors. *Significantly different from irradiated control cells at $p=0.05$. " Significantly different from control cells at $p=0.05$
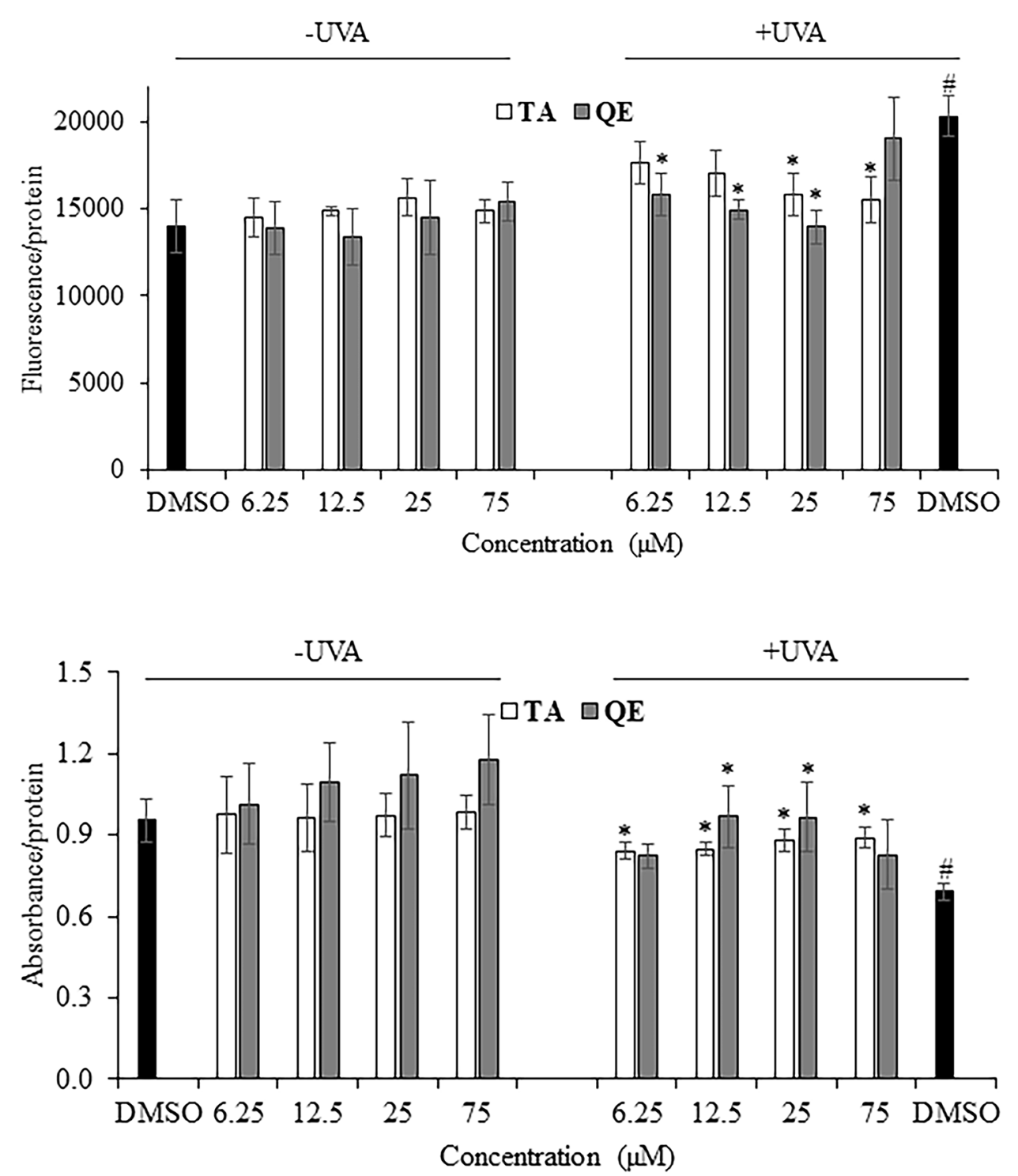

Fig. 4 Effect of flavonoids on UVA-induced GSH depletion in NHDF. Fibroblasts pre-treated with TA and QE $(1 \mathrm{~h})$ were nonirradiated (- UVA) or exposed to $10 \mathrm{~J} / \mathrm{cm}^{2}$ (+UVA) and after incubation (4 h), the level of intracellular GSH was evaluated as described in Materials and Methods. Results are mean \pm SD of 4 experiments employing cells from 4 donors. *Significantly different from irradiated control cells at $p=0.05$. "Significantly different from control cells at $p=0.05$ of selected Nrf2-driven genes was studied in both primary fibroblasts and keratinocytes. UVA radiation caused a significant Nrf2 nuclear accumulation in NHDF. TA and QE stimulated Nrf2 nuclear accumulation in both nonirradiated and irradiated fibroblasts. A moderate difference between cell response to QE and TA was found only in irradiated NHDF. The effect of both flavonoids was smaller compared with SFN at the same concentration in non-irradiated and irradiated NHDF. Both TA and QE, as well as SFN, increased the amount of nuclear Nrf2 in irradiated cells, but the effect was not significant. (Fig. 7).

In NHEK, UVA radiation also provoked Nrf2 nuclear translocation. However, stimulation in keratinocytes was lower compared to NHDF (205\% of control vs. $475 \%$ of control, respectively), see Fig. 7 vs. Fig. 8. TA and QE significantly increased the amount of nuclear Nrf2 in both non-irradiated and irradiated keratinocytes. In non-irradiated cells, the effect of flavonoids was significant and concentration dependent. In irradiated cells, QE was more potent than TA at the lower concentration $(6.25 \mu \mathrm{M})$ and its effect was comparable with that of SFN; however, it declines with concentration. Both flavonoids and SFN significantly increased Nrf2 nuclear translocation in irradiated NHEK (Fig. 8).

\subsection{Effect of flavonoids and UVA on selected cytoprotective genes/proteins in skin cells}

The effects of TA and QE pre-treatment on UVA-modulated protein and/or mRNA expression of selected oxidative stress markers, specifically HO-1, NQO1 and CAT were determined by Western blot and/or real-time PCR. In NHDF treated with flavonoids only (- UVA), a minimal effect on HO-1 amount was found. UVA radiation stimulated HO-1 protein increase to approximately $\sim 215 \%$ of the control. 


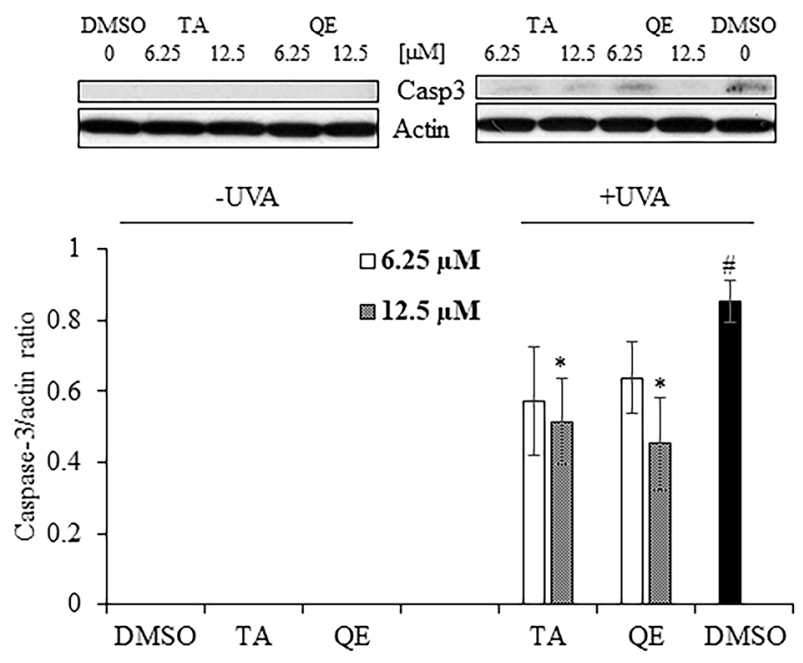

Fig. 5 Effect of flavonoids on UVA-induced caspase-3 activation in NHDF. Fibroblasts pre-treated with TA and QE $(1 \mathrm{~h})$ were non-irradiated (- UVA) or exposed to $10 \mathrm{~J} / \mathrm{cm}^{2}$ (+ UVA) and after incubation ( $24 \mathrm{~h}$ ), the level of active caspase-3 was evaluated by Western blot as described in Materials and Methods. Data are normalized to the reference protein actin. Results are mean $\pm \mathrm{SD}$ of 3 experiments employing cells from 3 donors. Representative examples of Western blot analysis are shown. *Significantly different from irradiated control cells at $p=0.05$. " Significantly different from control cells at $p=0.05$

In irradiated fibroblasts pre-treated with $\mathrm{TA}$ and $\mathrm{QE}$, the HO-1 level was increased compared to non-irradiated and irradiated cells, but there was no difference between the concentration of 6.25 and $12.5 \mu \mathrm{M}$. The effect of SFN on HO-1 protein level was minimal when compared to nonirradiated and irradiated fibroblasts (Fig. 9A). UVA exposure greatly enhanced the amount of HO-1 mRNA ( 550\% of control, Fig. 9B) in NHDF. The effect of flavonoids on non-irradiated cells was minimal, but SFN caused evident stimulation to $243 \%$ of control. In irradiated NHDF, TA increased HO-1 mRNA only at the lower concentration. QE stimulated HO-1 mRNA level at both concentrations, but the lower one was more effective. The effect of the flavonoids was higher compared to SFN at the same concentration $(6.25 \mu \mathrm{M})$ (Fig. 9B).

The response of keratinocytes to flavonoid treatment was stronger compared to NHDF. Both flavonoids stimulated HO-1 protein and mRNA level in non-irradiated cells; the effect of QE was concentration-dependent and higher than that of TA. On mRNA level, QE and TA were even more potent than SFN in non-irradiated keratinocytes. On protein level QE effect was comparable with SFN; the effect of TA on the amount of HO-1 protein was not apparent. HO-1 mRNA amount was significantly enhanced in irradiated NHEK pre-treated by both flavonoids. The effect of SFN $(6.25 \mu \mathrm{M})$ on UVA-treated keratinocytes was minimal (Fig. 10).
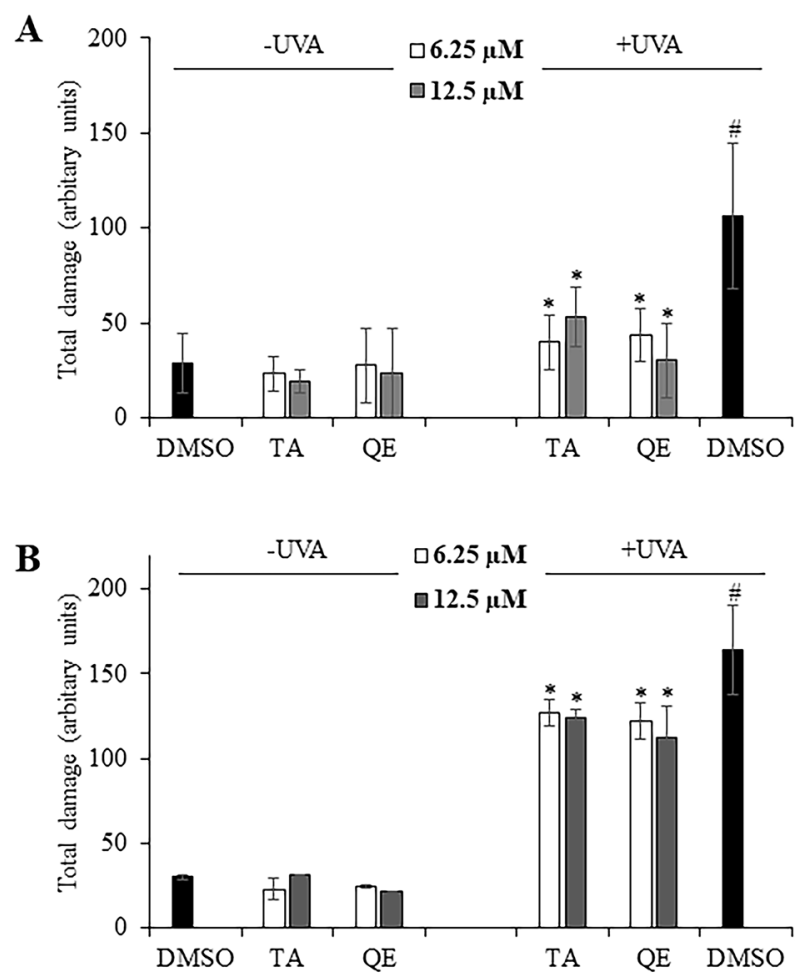

Fig. 6 Effect of flavonoids on UVA-induced single-strand breaks level in skin cells. NHDF (A) or NHEK (B) pre-treated with TA and QE $(1 \mathrm{~h})$ were non-irradiated (- UVA) or exposed to $10 \mathrm{~J} / \mathrm{cm}^{2}$ (+ UVA) and after $4 \mathrm{~h}$ of incubation, DNA damage was evaluated by comet assay as described in Materials and Methods. Results are mean \pm SD of 4 experiments employing cells from 4 donors. *Significantly different from irradiated control cells at $p=0.05$. "Significantly different from control cells at $p=0.05$

NQO1 protein level in UVA-treated fibroblasts was reduced to $\sim 67 \%$ of non-irradiated cells. The effect of the flavonoids and SFN was minimal on non-irradiated and irradiated cells (Fig. 11A). TA and QE also had minimal effects on NQO1 mRNA level in non-irradiated NHDF compared to SFN. UVA radiation caused a significant reduction in NQO1 mRNA level ( 45\% of control). Pretreatment of cells with the flavonoids and SFN eliminated the reduction, and moreover, it significantly elevated the NQO1 mRNA level. However, the flavonoids effect decreased with their increasing concentration. The effect of both TA and QE $(6.25 \mu \mathrm{M})$ was higher than that of SFN, see Fig. 11B.

In keratinocytes, the effect of UVA on NQO1 protein was comparable with fibroblasts, but was less pronounced (Fig. 12A). In non-irradiated cells, flavonoids and SFN showed no effect on the protein level. But in irradiated fibroblasts, both TA and QE non-significantly stimulated NQO1 protein expression and their effect was noticeably higher than that of SFN. The effect of UVA on NQO1 mRNA level was analogous to that on protein amount. TA and QE caused 
A

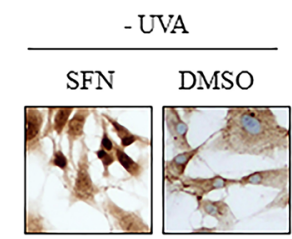

$6.25 \mu \mathrm{M} \quad 12.5$

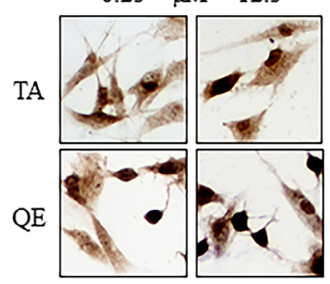

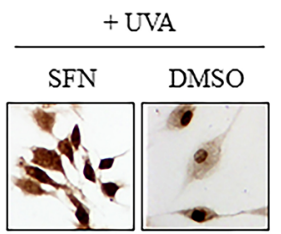

$6.25 \mu \mathrm{M} \quad 12.5$

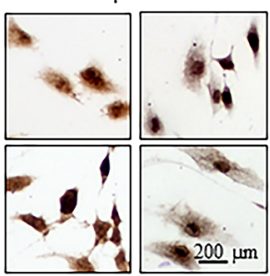

Fig. 7 Effect of flavonoids on UVA-affected Nrf2 nuclear translocation in NHDF. Nrf2 cellular localization (A) and semi-quantification (B) was determined in fibroblasts by immunocytochemistry. Cells pre-treated with TA and QE $(1 \mathrm{~h})$ were non-irradiated (- UVA) or exposed to $7.5 \mathrm{~J} / \mathrm{cm}^{2}$ (+UVA). After incubation $(3 \mathrm{~h})$, Nrf2 nuclear translocation was evaluated as described in Materials and Methods.

A
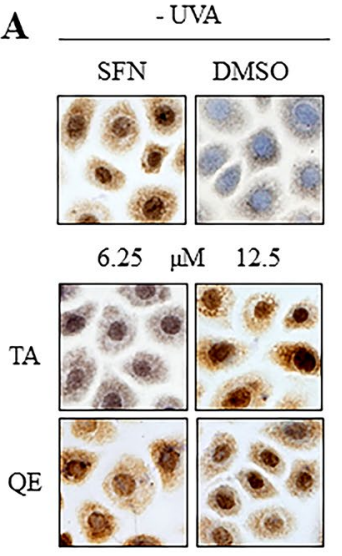

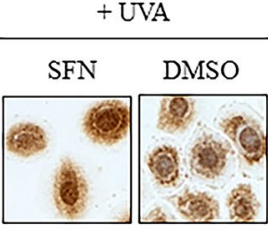

$6.25 \mu \mathrm{M} \quad 12.5$

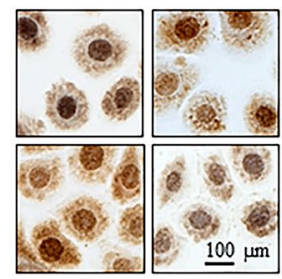

Fig. 8 Effect of flavonoids on UVA-affected Nrf2 nuclear translocation in NHEK. Nrf2 cellular localization (A) and semi-quantification (B) was determined in NHEK by immunocytochemistry. Cells pre-treated with TA and QE $(1 \mathrm{~h})$ were non-irradiated (- UVA) or exposed to $10 \mathrm{~J} / \mathrm{cm}^{2}$ (+UVA). After incubation $(6 \mathrm{~h})$, Nrf2 nuclear translocation was evaluated as described in Materials and Methods.

an mRNA level increase in non-irradiated as well as irradiated keratinocytes. However, the increase was not significant and there was no evident concentration-related effect. SFN stimulated a significant increase in NQO1 mRNA level in both non-irradiated and irradiated NHEK, its effect was more potent than that of the flavonoids (Fig. 12B).

In non-irradiated NHDF, only QE increased basal catalase level, comparable to SFN. As expected, CAT protein level was reduced in irradiated NHDF as well as NHEK (Fig. 13A and B). Pre-treatment of fibroblasts with TA and QE only insignificantly prevented UVA-caused CAT level reduction, however, only insignificantly. Similarly, a protective effect

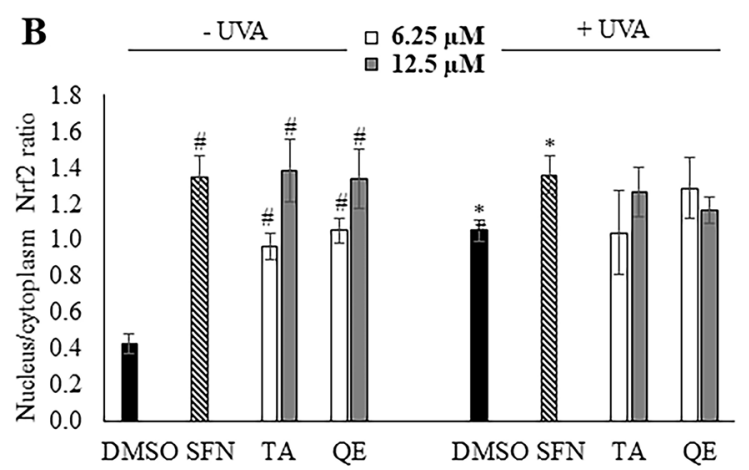

Results are mean \pm SD of 3 experiments employing cells from 3 donors. Microscopy images are representative from one of three independent donors. Haematoxylin was used for nuclei staining (blue). All panels are at 100 -fold magnification. *Significantly different from irradiated control cells at $p=0.05$. "Significantly different from control cells at $p=0.05$

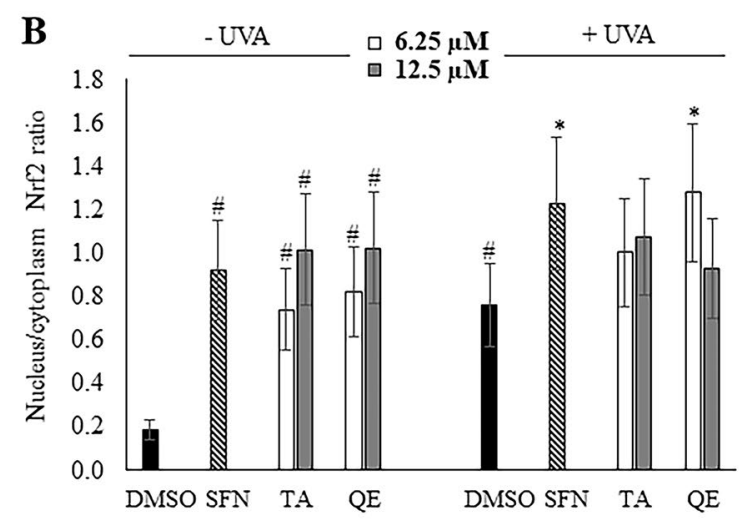

Results are mean \pm SD of 3 experiments employing cells from 3 donors. Microscopy images are representative from one of three independent donors. Haematoxylin was used for nuclei staining (blue). All panels are at 200-fold magnification. *Significantly different from irradiated control cells at $p=0.05$. "Significantly different from control cells at $p=0.05$

was found in SFN pre-treated cells (Fig. 13A). In non-irradiated NHEK treated with both flavonoids, an increased CAT basal level was detected. As shown in Fig. 13B, TA had no significant effect on UVA-induced CAT level decrease.

\section{Discussion}

Plenty of studies referring to the beneficial effects of QE on various disorders have been published, as documented in a recent review [6]. Among others, QE demonstrated interesting dermal activities in cellular and animal models, ranging 
Fig. 9 Effect of flavonoids on UVA-affected HO-1 level and expression in NHDF. HO-1 protein level was analysed by Western blot (A) and HO-1 mRNA level by qPCR $(\mathbf{B})$. Fibroblasts pre-treated with TA and QE $(1 \mathrm{~h})$ were nonirradiated (- UVA) or exposed to $7.5 \mathrm{~J} / \mathrm{cm}^{2}$ (+ UVA). After incubation (24 h), HO-1 level was evaluated as described in Materials and Methods. Data are normalized to the reference protein actin and gene GAPDH. Results are mean \pm SD of 3 experiments employing cells from 3 donors. Representative examples of Western blot analysis are shown. *Significantly different from irradiated control cells at $p=0.05$. "Significantly different from control cells at $p=0.05$
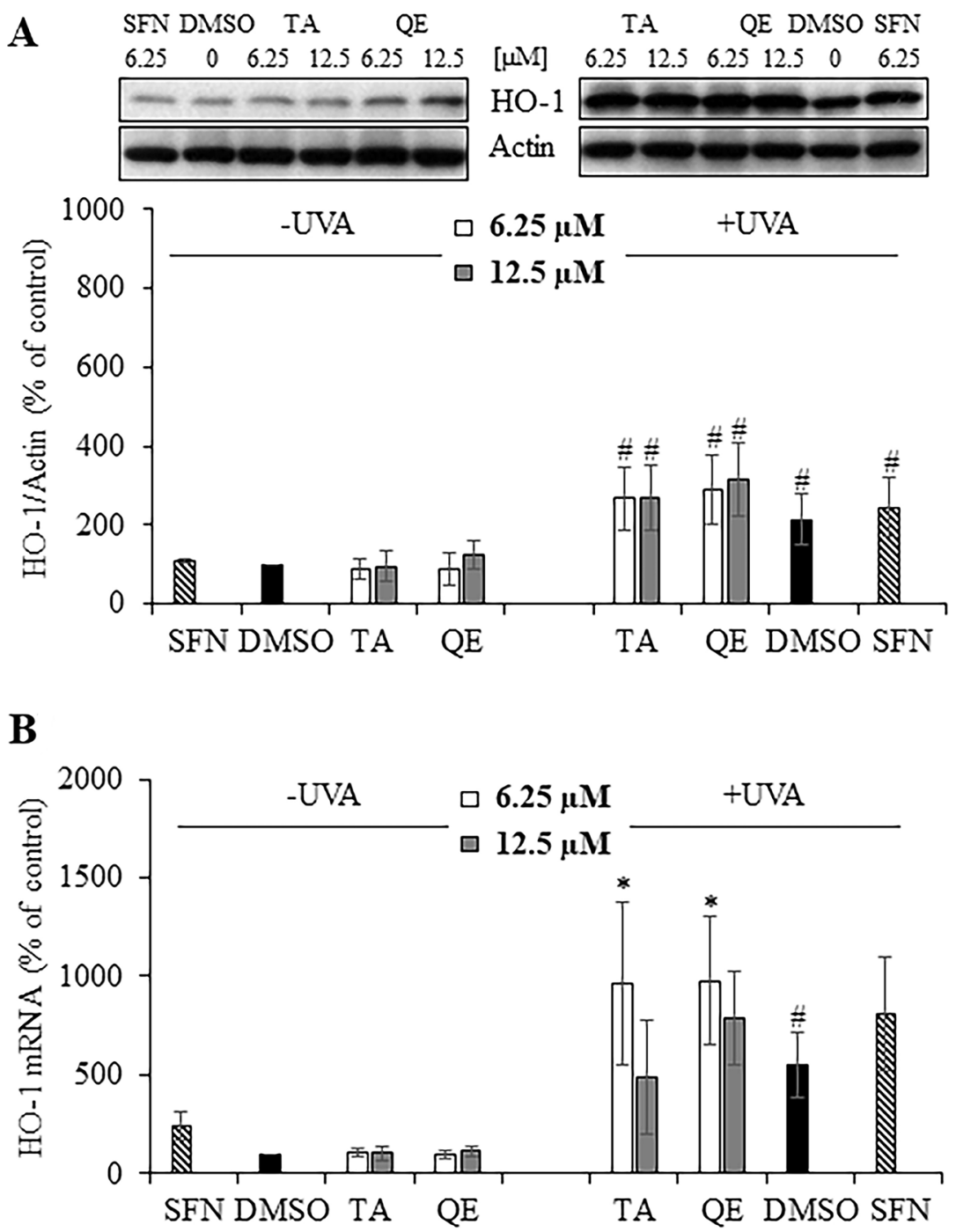

from protection against UV irradiation to supporting skin regeneration in wound healing [24]. QE was also studied in vitro as a potential sunscreen agent and, in combination with titanium dioxide, it demonstrated interesting SPF and PF-UVA values ( 30 and 17, respectively) [10]. On the other hand, several papers have described the instability and phototoxic potential of QE $[8,16,23]$. As such, in this study we assessed the ability of QE to suppress UVAinduced damage to both major skin cells, dermal fibroblasts and epidermal keratinocytes obtained from the same donor. The potency of QE was compared with its structural photostable derivative TA [23] and with SFN, a well-documented activator of the Nrf2 signalling pathway.

UVA radiation is well known to stimulate the enormous production of ROS that can overwhelm the antioxidant capacity of cells, resulting in attacks on various biomolecules, such as proteins, lipids and DNA, and oxidative damage to same [3]. We studied the capability of the flavonoids in question to prevent intracellular ROS level formation, depletion of GSH (the most abundant non-enzymatic antioxidant) and DNA SSBs production. Pre-treatment with QE and TA reduced ROS level, GSH depletion and caspase-3 activation in NHDF and decreased the formation of DNA SSBs in both fibroblasts and keratinocytes (Figs. 3, 4, 5, and 6). Our findings correspond with a previous study by Kimura et al. who found reduced ROS generation and GSH depletion in HaCaT keratinocytes pre-treated with QE and exposed to UVA $\left(30 \mathrm{~J} / \mathrm{cm}^{2}\right)$. They also demonstrated a significant increase in the basal level of GSH in non-irradiated cells treated with QE [15]. This QE effect was also observed in our experiments. Another report described the prevention of GSH depletion in female Sprague-Dawley rats intraperitoneally treated with $\mathrm{QE}$ and repeatedly irradiated with UVA light [12]. TA protection against UVA radiation was only poorly studied. However, the application of TA reduced ROS production in human keratinocytes HaCaT and mouse fibroblasts BALB/c [25] intoxicated with hydrogen peroxide, used to simulate UVA radiation. TA was also found to 
Fig. 10 Effect of flavonoids on UVA-affected HO-1 level and expression in NHEK. HO-1 protein level was analysed by Western blot (A) and HO-1 mRNA level by qPCR $(\mathbf{B})$. NHEK pre-treated with TA and QE (1 h) were non-irradiated ( - UVA) or exposed to $10 \mathrm{~J} /$ $\mathrm{cm}^{2}$ (+UVA). After incubation $(6 \mathrm{~h}), \mathrm{HO}-1$ level was evaluated as described in Materials and Methods. Data are normalized to the reference protein actin and gene GAPDH. Results are mean \pm SD of 3 experiments employing cells from 3 donors. Representative examples of Western blot analysis are shown. *Significantly different from irradiated control cells at $p=0.05 .{ }^{\text {\#Significantly different }}$ from control cells at $p=0.05$

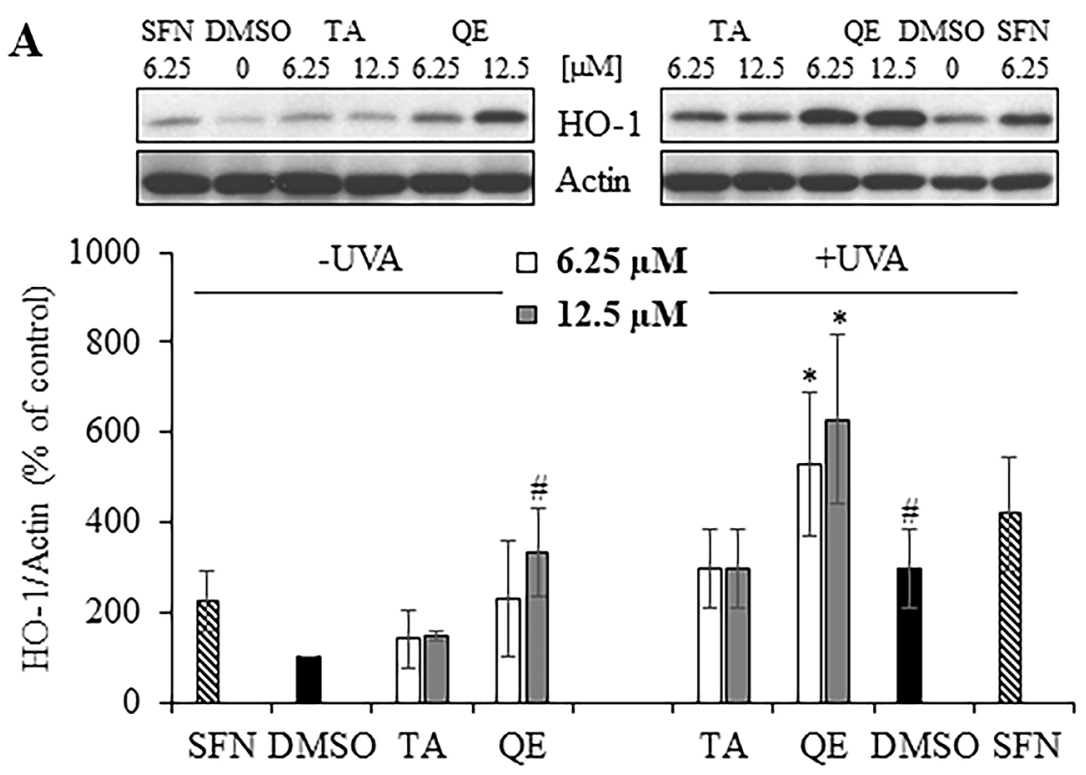

B

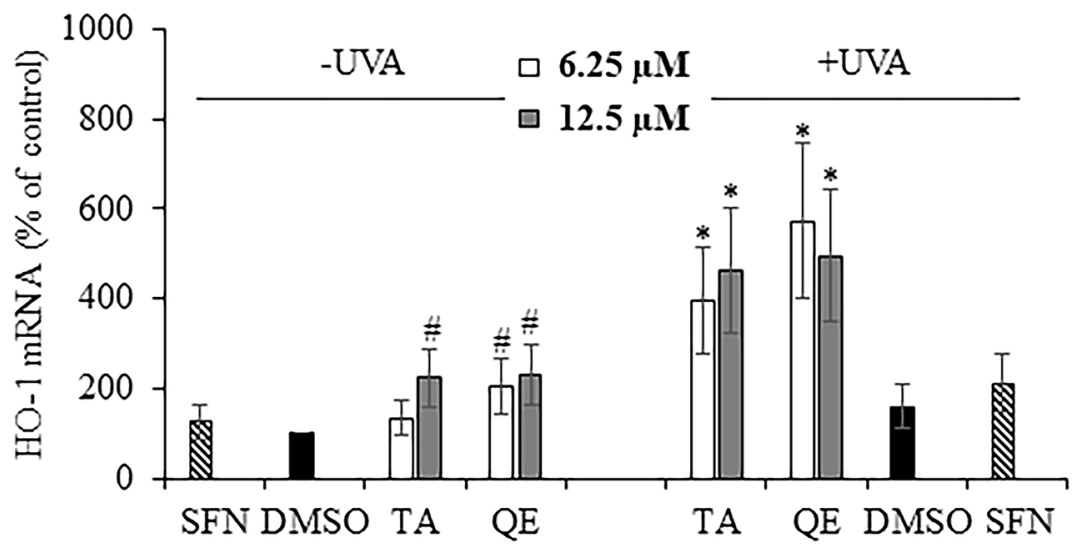

protect white blood cells against hydrogen peroxide-induced DNA SSBs [26]. The effect of QE on SSBs formation was probably not studied, but it reduced another well-recognized biomarker of DNA oxidative damage, 8-hydroxydeoxyguanosine, in UVA exposed B16F10 cells [27].

Skin cells have developed effective mechanisms to protect against oxidative damage. A major regulator of the cellular antioxidant defence is the nuclear factor Nrf2 [3]. This transcription factor induces the expression of many genes; some of these are involved in the cellular redox balance. As such, pharmacological Nrf2 activation seems to be a promising strategy for skin protection under stress conditions, including exposure to UVA radiation [28]. Here, we showed UVA-induced Nrf2 nuclear accumulation in both NHDF and NHEK. The translocation was noticeably smaller in NHEK compared to NHDF (Figs. 7 and 8). This might be associated with the functional autophagy mechanism in NHEK that is responsible for the efficient degradation and recycling of oxidatively modified cellular components.
Zhao et al. demonstrated that impaired autophagy results in elevated Nrf2-dependent genes in autophagy-deficient keratinocytes [29]. The less-pronounced effect of UVA on keratinocytes may also be associated with the higher antioxidant capacity of keratinocytes, such as a higher level of constitutively expressed HO-2 [30] or higher level of GSH [31] when compared to fibroblasts. The flavonoids studied here stimulated Nrf2 nuclear accumulation in both non-irradiated and irradiated primary skin cells (Figs. 7 and 8). QE and TA also increased HO-1 protein and mRNA expression in irradiated NHDF and NHEK, except for TA on protein level in keratinocytes (Figs. 9 and 10). Both flavonoids further enhanced NQO1 protein and mRNA expression in NHEK and only mRNA expression in NHDF following UVA treatment (Figs. 11 and 12). Our results for the mentioned parameters are in agreement with published data. QE treatment $(1-100 \mu \mathrm{M})$ caused the concentration-dependent accumulation of Nrf2 protein and up-regulated mRNA level of Nrf2 driven genes including HO-1 in HaCaT keratinocytes [15]. 
Fig. 11 Effect of flavonoids on UVA-affected NQO1 level and expression in NHDF. NQO1 protein level was analysed by Western blot (A) and NQO1 mRNA level by qPCR (B). Fibroblasts pre-treated with TA and QE (1 h) were nonirradiated (- UVA) or exposed to $7.5 \mathrm{~J} / \mathrm{cm}^{2}$ (+ UVA). After incubation (24 h), HO-1 level was evaluated as described in Materials and Methods. Data are normalized to the reference protein actin and gene GAPDH. Results are mean \pm SD of 3 experiments employing cells from 3 donors. Representative examples of Western blot analysis are shown. *Significantly different from irradiated control cells at $p=0.05$. "Significantly different from control cells at $p=0.05$

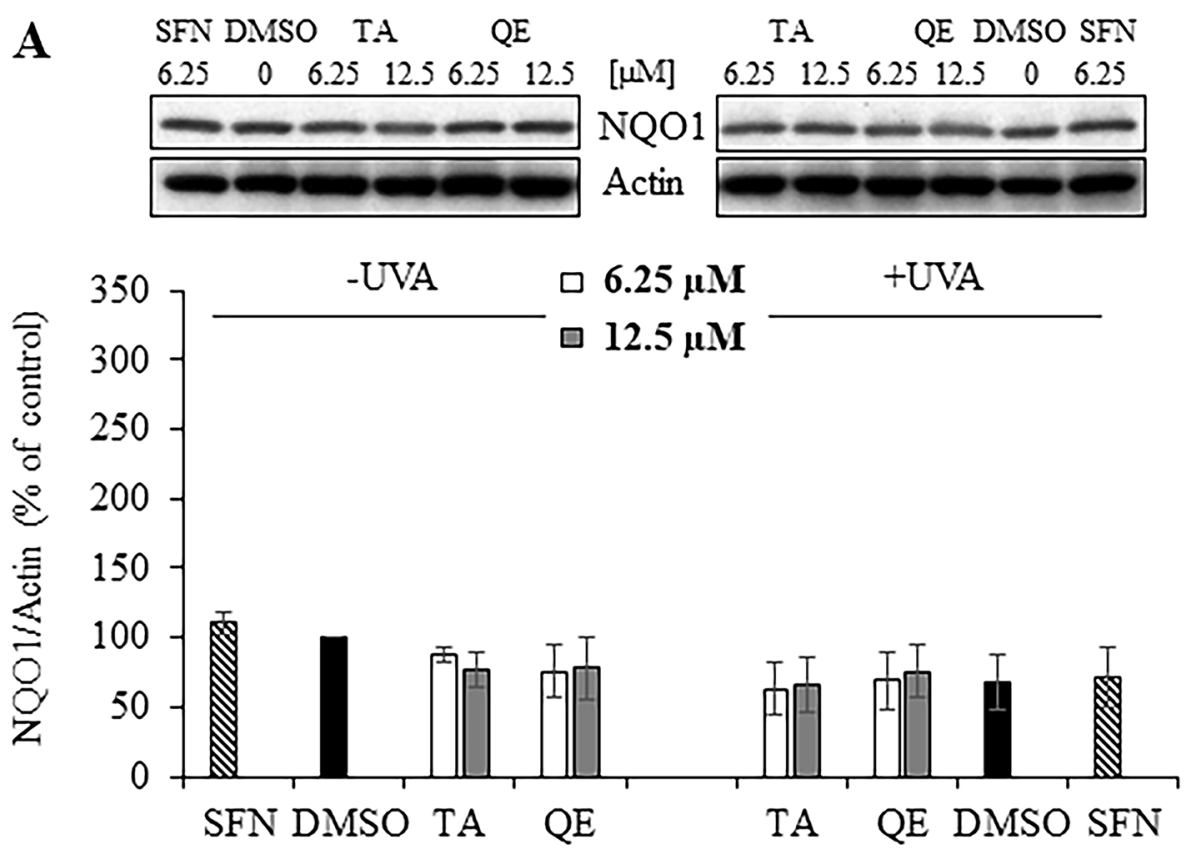

B

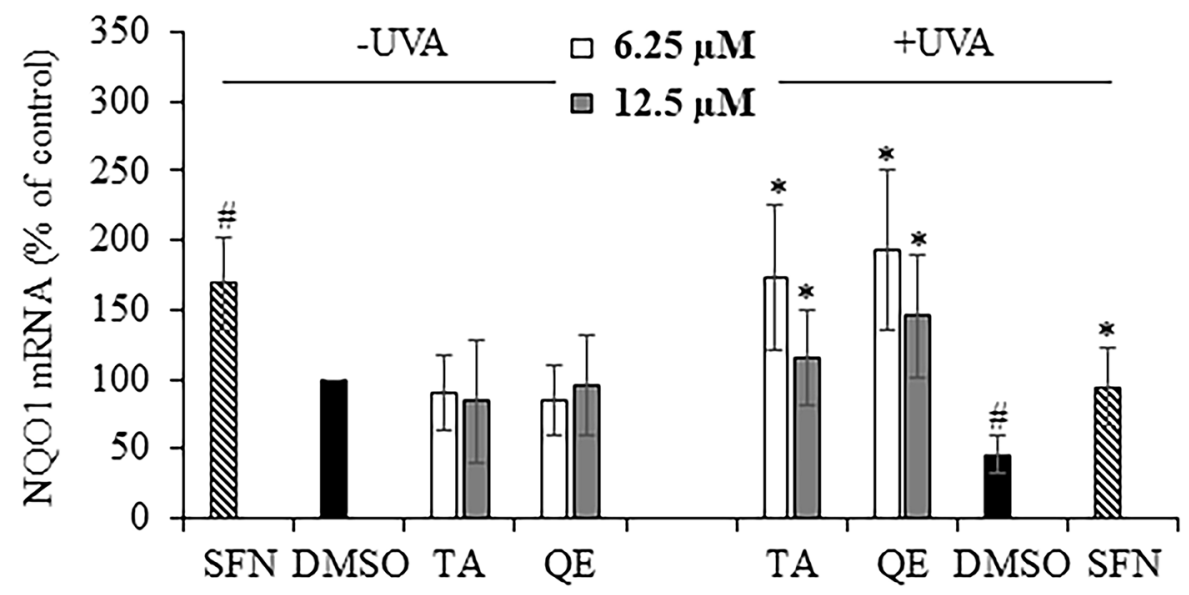

A similar effect of QE on Nrf2 nuclear translocation, as well as expression and activity of NQO1, was found in UVAexposed B16F10 [27]. In several types of cells, the application of TA increased protein and/or mRNA level of Nrf2, HO-1 and NQO1 [32-34]. A recent study using benzo[a] pyrene to stimulate oxidative damage showed that TA pretreatment of Swiss albino mice increased Nrf2 expression and nuclear translocation, NQO1, HO-1 and other Nrf2driven antioxidant enzymes protein levels in lung tissue. TA pre-treatment also had a beneficial effect on benzo[a] pyrene-induced GSH depletion, GSSG and malondialdehyde formation [35]. TA administration further reduced oxidative stress provoked by kidney obstruction in male C57BL6 mice, particularly increasing Nrf2, NQO1, HO-1 and CAT protein expression [36]. CAT is another essential enzyme that protects cells from oxidative damage. CAT expression was found to be reduced in Nrf2 knockout mice [37] and thus it most probably belongs to the group of genes controlled by Nrf2. A significant CAT reduction following UVA exposure was described previously in vitro [38] and in vivo [39]. Here, we detected similar CAT decreases in both irradiated NHDF and NHEK. Pre-treatment with the flavonoids reduced the decrease in irradiated fibroblasts. In keratinocytes, no significant effect was found (Fig. 13). QEs protective effect on CAT was previously demonstrated in female Sprague-Dawley rats, where QE pre-treatment increased CAT activity/level in erythrocytes and liver tissue of nonirradiated animals as well as in skin, erythrocytes and liver of UVA exposed animals [11-13].

When comparing both of the tested flavonoids, QE is a stronger antioxidant than TA, as documented in both experimental and theoretical studies [40-42]. The 
Fig. 12 Effect of flavonoids on UVA-affected NQO1 level and expression NHEK. NQO1 protein level was analysed by Western blot (A) and NQO1 mRNA level by qPCR (B). Keratinocytes pre-treated with TA and QE (1 h) were nonirradiated (- UVA) or exposed to $10 \mathrm{~J} / \mathrm{cm}^{2}$ (+UVA). After incubation (24 h), HO-1 level was evaluated as described in Materials and Methods. Data are normalized to the reference protein actin and gene GAPDH. Results are mean \pm SD of 3 experiments employing cells from 3 donors. Representative examples of Western blot analysis are shown. *Significantly different from irradiated control cells at $p=0.05$

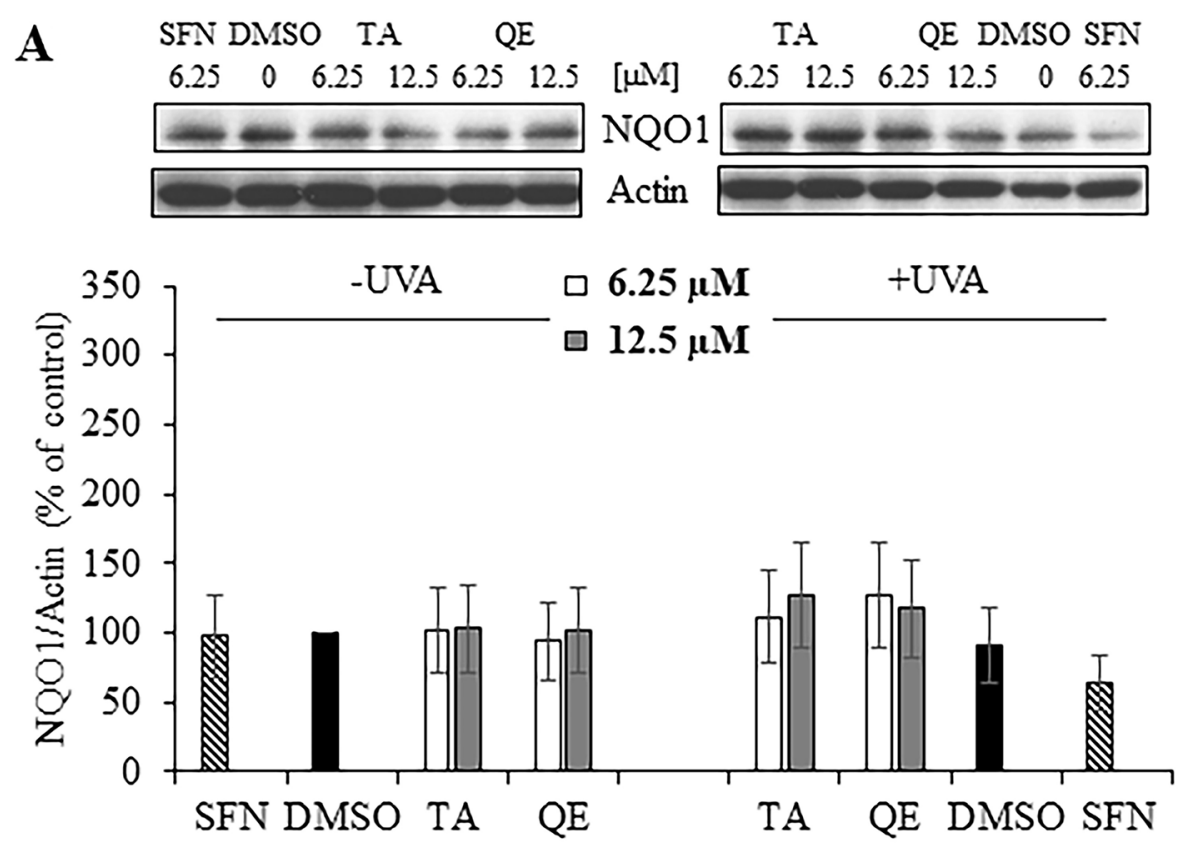

B

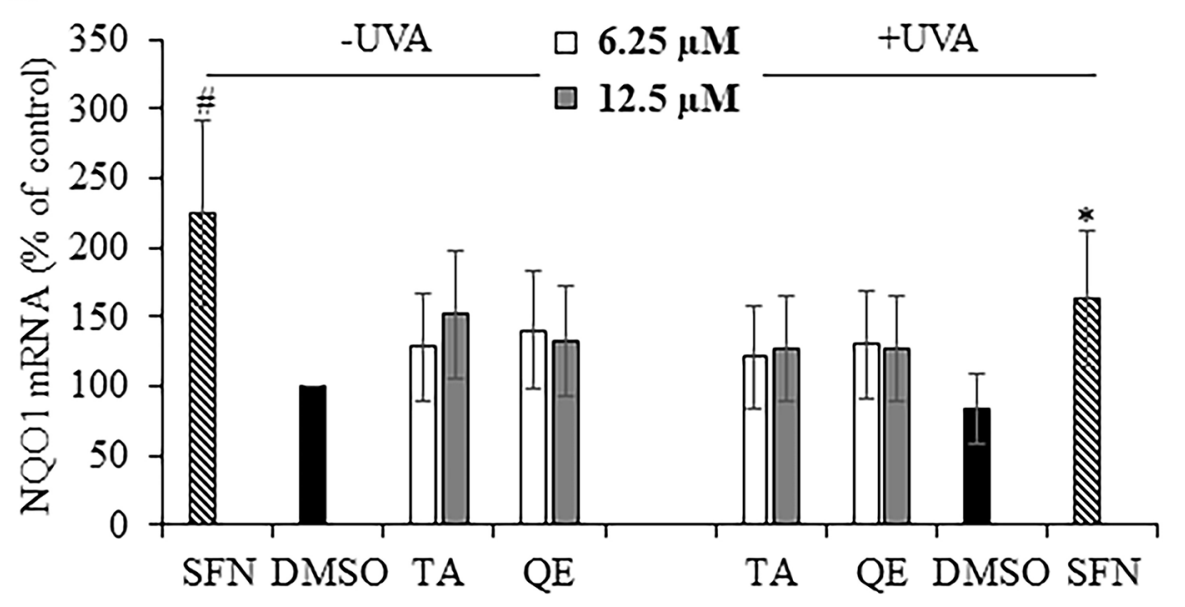

presence of a 2,3-double bond in the structure of QE contributes to its more potent antioxidant activity. Osorio et al. further suggest that the stronger QE antioxidant activity results from the capability of the radicals arising from QE to persist longer in the environment [42]. On the other hand, it was clearly demonstrated that QE behaves not only as an antioxidant but also as a pro-oxidant, depending on concentration and free radical source [43]. In our previous study, we have demonstrated that QE undergoes degradation in culture medium (DMEM) in contrast to TA that is stable. However, inside the cells (NHDF), QE was stable and in 300-times higher concentration compared to TA [23]. Our study as well as paper by Dall'Acqua et al. have further demonstrated that the structure of QE is susceptible to breakdown and the formation of reactive (photo)degradation products $[16,23]$ that consequently can provoke cellular damage. These undesirable properties were not found for TA, which is photostable and non-phototoxic [23]. A product of the oxidative degradation of QE, $o$-quinone of quercetin (QQ), which has four tautomeric forms, i.e., the $o$-quinone and three quinone methides, was found to strongly react with the most abundant intracellular thiol, GSH, to form 6-glutathionylquercetin and 8-glutathionylquercetin. In the absence of GSH (e.g., such as in plasma), QQ interacts with protein sulfhydryl groups, causing their arylation which leads to loss of function [44]. Li et al. confirmed the formation of QE-GSH conjugates in human endothelial cells. Conjugate formation was accompanied by a significant temporary (after 3 and $6 \mathrm{~h}$ ) GSH depletion without GSSG formation, suggesting that GSH level was not decreased due to its oxidation (GSSG formation). The GSH decrease was 
$\mathbf{A}$
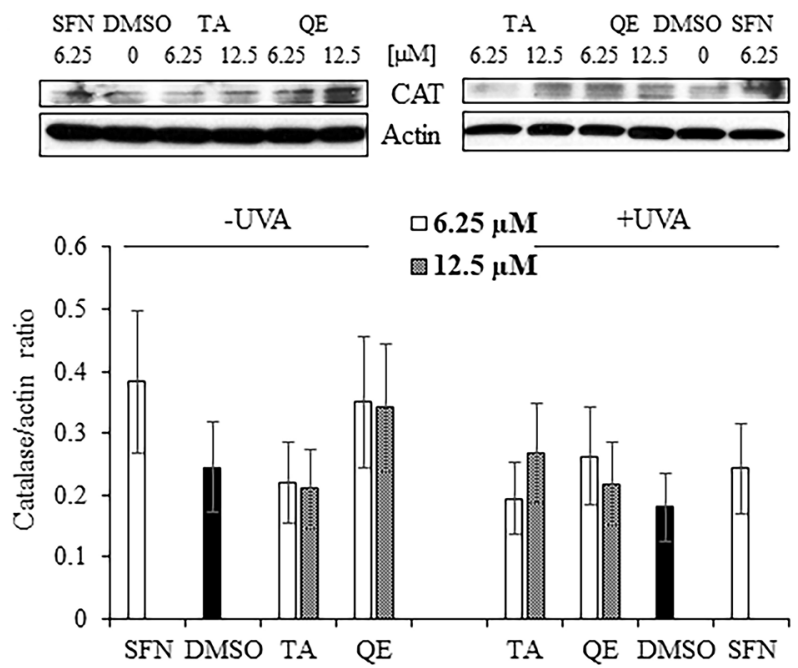

Fig. 13 Effect of flavonoids on UVA-affected on CAT level in skin cells. NHDF (A) or NHEK (B) pre-treated with TA and QE $(1 \mathrm{~h})$ were non-irradiated (- UVA) or exposed to 7.5 or $10 \mathrm{~J} / \mathrm{cm}^{2}$ (+ UVA), respectively. After incubation, CAT protein level was analysed by Western blot as described in Materials and Methods. Data are normalized to the reference protein actin. Graphs represent quantification

accompanied by increased mRNA and protein expression of glutamate-cysteine ligase (GCL), the enzyme catalysing the rate-limiting step in GSH synthesis, and that GSH level recovered within $18 \mathrm{~h}$ [45]. As GCL is under Nrf2 control, QE-GSH conjugates themselves or their formation may result in Nrf2 activation. Boots et al. described this behaviour of QE as the "quercetin paradox", i.e., the flavonoid becomes toxic as a result of its protection, by forming an oxidation product QQ, that can cause thiol arylation [46]. A recent computational study further indicates that both $\mathrm{QE}$ as well as its oxidized products, namely, 2-(3,4-dihydroxybenzoyl)-2,4,6-trihydroxy-3(2H)-benzofuranone, can interact with Keap1. As a result, interaction between Nrf2 and Keap1 is disrupted, Nrf2 is translocated to the nucleus and promotes expression of Nrf2-driven genes [47]. We have recently demonstrated that QE pretreatment followed by exposure to a non-toxic UVA dose $\left(5 \mathrm{~J} / \mathrm{cm}^{2}\right)$ caused increased ROS production and GSH depletion in NHDF. We also showed that QE phototoxicity increases with increasing UVA dose [23]. Here, we have also observed the loss of protective activity against ROS generation and GSH depletion at the highest QE concentration of $75 \mu \mathrm{M}$ (Figs. 3 and 4 ) that may be associated with increased production of QE oxidation product(s) and its pro-oxidant properties. In a recent study, we have also found greater QE skin intake compared to its analogue TA [48]. Similarly, we detected a much higher bioavailability of QE in NHDF compared to TA [23]. All these properties may contribute to the more pronounced biological effects of QE. Despite these results, we only found differences in
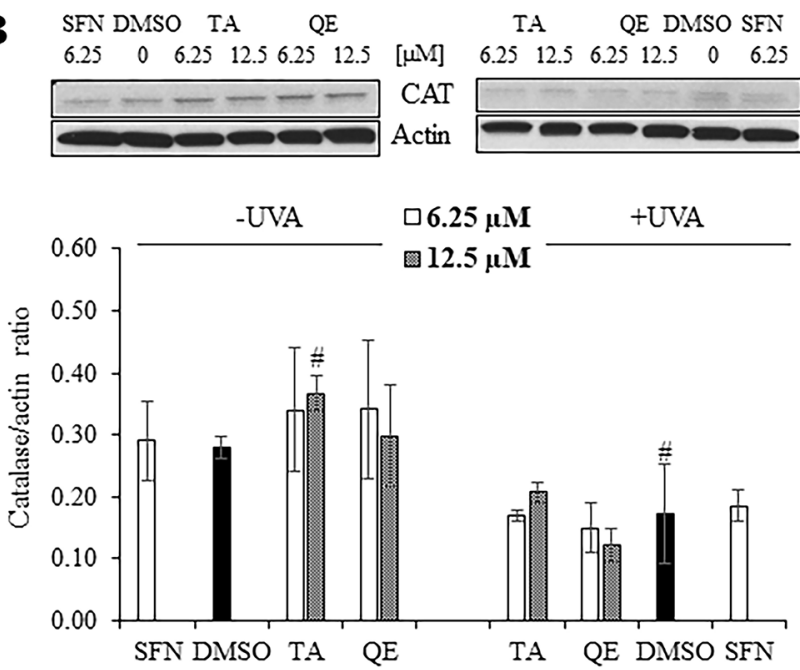

of Western blots from 3 independent experiments (donors). Data are expressed as the mean \pm SD. Representative examples of Western blot analysis are shown. *Significantly different from irradiated control cells at $p=0.05$. ${ }^{\#}$ Significantly different from control cells at $p=0.05$. ${ }^{\#}$ Significantly different from control cells at $p=0.05$

TA and QE protection for some parameters. The higher effectiveness of QE was most visibly detected on ROS level in NHDF and Nfr-2 nuclear accumulation and HO-1 expression in NHEK. Several previous studies found that QE was a more potent effector of the Nrf2 signalling pathway than its structurally related compounds. For example, TA (different due to the presence of a 2,3-double bond in ring C) [25], kaempferol or galangin (differences in the number of hydroxyl groups in ring B) [14], luteolin (difference in the presence of a 3-hydroxyl group in ring C) [49] or rutin (quercetin-3-O-rutinoside) $[27,49,50]$.

In summary, we have shown that $\mathrm{QE}$ and TA pre-treatment of primary skin fibroblasts and keratinocytes isolated from one donor can at least partially reduce UVA-induced damage. Their UVA protective effects are linked to the stimulation of Nrf2 nuclear translocation and expression of antioxidant proteins, such as HO-1 and NQO1, which is accompanied by a reduction of UVA-stimulated ROS generation and related cellular events, such as GSH depletion, single-strand breaks production, and catalase protection. All these events increase the capacity of the cell to overcome UVA-provoked damage. On the other hand, we also noticed decreased protection by $\mathrm{QE}$ at the highest tested concentration $(75 \mu \mathrm{M})$, which may confirm the pro-oxidative potential of the compound at high concentrations. The prooxidative properties may be especially serious at high QE concentrations in combination with high UVA doses. Taken together with previously published works, the potential negative effect of QE (the "quercetin paradox") must be taken into consideration. Further studies should be performed to 
confirm our results on more sophisticated models, such as human skin ex vivo or in clinical studies.

Acknowledgements We would like to express our thanks Iveta Hatalová (University Hospital Olomouc) for the support with skin tissue donor recruitment and Dr. Jana Franková (Department of Medical Chemistry and Biochemistry) for the extraction of human primary epidermal keratinocytes.

Author contributions ARS and JVo designed the experiments, performed some experiments (ROS generation, GSH level, DNA damage) and wrote the first draft of the manuscript. AR was responsible for preparation of samples for immunocytochemical, Western blot and RT-PCR analysis. She also performed and evaluated Western blots. KC was responsible for the evaluation of immunocytochemical sections. LR and JVr were responsible for RT-PCR analysis. BZ was responsible for recruitment of skin tissue donors and sample collection. JU was responsible for critical proofreading of data and the text of the manuscript. All authors read and approved the final manuscript.

Funding This study was financially supported by the grants IGA_ LF_2021_011 and the Institutional Support of Palacký University, Olomouc-RVO 61989592.

\section{Declarations}

Conflict of interest The authors have no relevant financial or non-financial interests to disclose.

Ethics approval The Ethics Committee of University Hospital Olomouc and the Faculty of Medicine and Dentistry, Palacký University, Olomouc approved the use of superfluous skin from human volunteers (ref. number 41/09). All volunteers signed their written informed consent.

Consent of publication All authors agree with the publication of this manuscript.

\section{References}

1. Svobodová, A., Walterová, D., \& Vostálová, J. (2006). Ultraviolet light-induced alteration to the skin. Biomedical Papers of the Faculty of Medicine of Palacký University, Olomouc Czech Republic, 150(1), 25-38. https://doi.org/10.5507/bp.2006.003

2. Gęgotek, A., \& Skrzydlewska, E. (2015). The role of transcription factor Nrf2 in skin cells metabolism. Archives of Dermatological Research, 307(5), 385-396. https://doi.org/10.1007/ s00403-015-1554-2

3. Svobodová, A., \& Vostálová, J. (2010). Solar radiation induced skin damage: Review of protective and preventive options. International Journal of Radiation Biology, 86(12), 999-1030. https:// doi.org/10.3109/09553002.2010.501842

4. Saewan, N., \& Jimtaisong, A. (2015). Natural products as photoprotection. Journal of Cosmetic Dermatology, 14(1), 47-63. https://doi.org/10.1111/jocd.12123

5. Andres, S., Pevny, S., Ziegenhagen, R., Bakhiya, N., Schäfer, B., Hirsch-Ernst, K. I., \& Lampen, A. (2018). Safety aspects of the use of quercetin as a dietary supplement. Molecular Nutrition \& Food Research, 62(1), 1. https://doi.org/10.1002/mnfr.201700447
6. D'Andrea, G. (2015). Quercetin: A flavonol with multifaceted therapeutic applications? Fitoterapia, 106, 256-271. https://doi. org/10.1016/j.fitote.2015.09.018

7. Zhu, X., Li, N., Wang, Y., Ding, L., Chen, H., Yu, Y., \& Shi, X. (2017). Protective effects of quercetin on UVB irradiation-induced cytotoxicity through ROS clearance in keratinocyte cells. Oncology Reports, 37(1), 209-218. https://doi.org/10.3892/or.2016. 5217

8. Casagrande, R., Georgetti, S. R., Verri, W. A., Jr., Dorta, D. J., dos Santos, A. C., \& Fonseca, M. J. (2006). Protective effect of topical formulations containing quercetin against UVB-induced oxidative stress in hairless mice. Journal of Photochemistry and Photobiology B: Biology, 84(1), 21-27. https://doi.org/10.1016/j. jphotobiol.2006.01.006

9. Vicentini, F. T., Simi, T. R., Del Ciampo, J. O., Wolga, N. O., Pitol, D. L., Iyomasa, M. M., Bentley, M. V., \& Fonseca, M. J. (2008). Quercetin in w/o microemulsion: In vitro and in vivo skin penetration and efficacy against UVB-induced skin damages evaluated in vivo. European Journal of Pharmaceutics and Biopharmaceutics, 69(3), 948-957. https://doi.org/10.1016/j.ejpb. 2008.01.012

10. Choquenet, B., Couteau, C., Paparis, E., \& Coiffard, L. J. (2008). Quercetin and rutin as potential sunscreen agents: Determination of efficacy by an in vitro method. Journal of Natural Products, 71(6), 1117-1118. https://doi.org/10.1021/np7007297

11. Erden Inal, M., \& Kahraman, A. (2000). The protective effect of flavonol quercetin against ultraviolet a induced oxidative stress in rats. Toxicology, 154(1-3), 21-29. https://doi.org/10.1016/s0300483x(00)00268-7

12. Erden Inal, M., Kahraman, A., \& Köken, T. (2001). Beneficial effects of quercetin on oxidative stress induced by ultraviolet A. Clinical and Experimental Dermatology, 26(6), 536-539. https:// doi.org/10.1046/j.1365-2230.2001.00884.x

13. Kahraman, A., \& Erden Inal, M. (2002). Protective effects of quercetin on ultraviolet A light-induced oxidative stress in the blood of rat. Journal of Applied Toxicology, 22(5), 303-309. https://doi.org/10.1002/jat.863

14. Maini, S., Fahlman, B. M., \& Krol, E. S. (2015). Flavonols protect against UV radiation-induced thymine dimer formation in an artificial skin mimic. Journal of Pharmacy and Pharmaceutical Sciences, 18(4), 600-615. https://doi.org/10.18433/j34w39

15. Kimura, S., Warabi, E., Yanagawa, T., Ma, D., Itoh, K., Ishii, Y., Kawachi, Y., \& Ishii, T. (2009). Essential role of Nrf2 in keratinocyte protection from UVA by quercetin. Biochemical and Biophysical Research Communications, 387(1), 109-114. https://doi. org/10.1016/j.bbrc.2009.06.136

16. Dall'Acqua, S., Miolo, G., Innocenti, G., \& Caffieri, S. (2012). The photodegradation of quercetin: Relation to oxidation. Molecules, 17(8), 8898-8907. https://doi.org/10.3390/molecules1 7088898

17. Minner, F., Herphelin, F., \& Poumay, Y. (2010). Study of epidermal differentiation in human keratinocytes cultured in autocrine conditions. Methods in Molecular Biology, 585, 71-82. https:// doi.org/10.1007/978-1-60761-380-0_6

18. Pivodová, V., Franková, J., Galandáková, A., \& Ulrichová, J. (2015). In vitro AuNPs' cytotoxicity and their effect on wound healing. Nanobiomedicine (Rij), 2, 7. https://doi.org/10.5772/ 61132

19. RajnochováSvobodová, A., Zálešák, B., Biedermann, D., Ulrichová, J., \& Vostálová, J. (2016). Phototoxic potential of silymarin and its bioactive components. Journal of Photochemistry and Photobiology B: Biology, 156, 61-68. https://doi.org/10. 1016/j.jphotobiol.2016.01.011

20. RajnochováSvobodová, A., Gabrielová, E., Michaelides, L., Kosina, P., Ryšavá, A., Ulrichová, J., Zálešák, B., \& Vostálová, J. (2018). UVA-photoprotective potential of silymarin and 
silybin. Archives of Dermatological Research, 310(5), 413-424. https://doi.org/10.1007/s00403-018-1828-6

21. Ryšavá, A., Č́̌žková, K., Franková, J., Roubalová, L., Ulrichová, J., Vostálová, J., Vrba, J., Zálešák, B., \& RajnochováSvobodová, A. (2020). Effect of UVA radiation on the Nrf2 signalling pathway in human skin cells. Journal of Photochemistry and Photobiology B: Biology, 209, 111948. https://doi.org/10.1016/j. jphotobiol.2020.111948

22. Livak, K. J., \& Schmittgen, T. D. (2001). Analysis of relative gene expression data using real-time quantitative PCR and the 2(-Delta Delta C(T)) method. Methods, 25(4), 402-408. https:// doi.org/10.1006/meth.2001.1262

23. Rajnochová Svobodová, A., Ryšavá, A., Psotová, M., Kosina, P., Zálešák, B., Ulrichová, J., \& Vostálová, J. (2017). The phototoxic potential of the flavonoids, taxifolin and quercetin. Photochemistry and Photobiology, 93(5), 1240-1247. https://doi. org/10.1111/php. 12755

24. Hatahet, T., Morille, M., Hommoss, A., Devoisselle, J. M., Müller, R. H., \& Bégu, S. (2016). Quercetin topical application, from conventional dosage forms to nanodosage forms. European Journal of Pharmaceutics and Biopharmaceutics, 108, 41-53. https://doi.org/10.1016/j.ejpb.2016.08.011

25. Svobodová, A., Walterová, D., \& Psotová, J. (2006). Influence of silymarin and its flavonolignans on $\mathrm{H}(2) \mathrm{O}(2)$-induced oxidative stress in human keratinocytes and mouse fibroblasts. Burns, 32(8), 973-979. https://doi.org/10.1016/j.burns.2006.04.004

26. Živković, L., Bajić, V., Topalović, D., Bruić, M., \& SpremoPotparević, B. (2019). Antigenotoxic effects of biochaga and dihydroquercetin (taxifolin) on $\mathrm{H}_{2} \mathrm{O}_{2}$-induced DNA damage in human whole blood cells. Oxidative Medicine and Cellular Longevity. https://doi.org/10.1155/2019/5039372

27. Chaiprasongsuk, A., Onkoksoong, T., Pluemsamran, T., Limsaengurai, S., \& Panich, U. (2016). Photoprotection by dietary phenolics against melanogenesis induced by UVA through Nrf2-dependent antioxidant responses. Redox Biology, 8, 79-90. https://doi.org/10.1016/j.redox.2015.12.006

28. Ryšavá, A., Vostálová, J., \& RajnochováSvobodová, A. (2021). Effect of ultraviolet radiation on the Nrf2 signalling pathway in skin cells. International Journal of Radiation Biology. https:// doi.org/10.1080/09553002.2021.1962566

29. Zhao, Y., Zhang, C. F., Rossiter, H., Eckhart, L., König, U., Karner, S., Mildner, M., Bochkov, V. N., Tschachler, E., \& Gruber, F. (2013). Autophagy is induced by UVA and promotes removal of oxidized phospholipids and protein aggregates in epidermal keratinocytes. Journal of Investigative Dermatology, 133(6), 1629-1637. https://doi.org/10.1038/jid.2013.26

30. Applegate, L. A., Noël, A., Vile, G., Frenk, E., \& Tyrrell, R. M. (1995). Two genes contribute to different extents to the heme oxygenase enzyme activity measured in cultured human skin fibroblasts and keratinocytes: Implications for protection against oxidant stress. Photochemistry and Photobiology, 61(3), 285-291. https://doi.org/10.1111/j.1751-1097.1995.tb03973.x

31. Niggli, H. J., \& Applegate, L. A. (1997). Glutathione response after UVA irradiation in mitotic and postmitotic human skin fibroblasts and keratinocytes. Photochemistry and Photobiology, 65(4), 680-684. https://doi.org/10.1111/j.1751-1097.1997. tb01911.x

32. Kuang, H., Tang, Z., Zhang, C., Wang, Z., Li, W., Yang, C., Wang, Q., Yang, B., \& Kong, A. N. (2017). Taxifolin activates the Nrf2 anti-oxidative stress pathway in mouse skin epidermal JB6 P+ cells through epigenetic modifications. International Journal of Molecular Sciences, 18(7), 1546. https://doi.org/10.3390/ijms1 8071546

33. Xie, X., Feng, J., Kang, Z., Zhang, S., Zhang, L., Zhang, Y., Li, X., \& Tang, Y. (2017). Taxifolin protects RPE cells against oxidative stress-induced apoptosis. Molecular Vision, 23, 520-528.
34. Liang, L., Gao, C., Luo, M., Wang, W., Zhao, C., Zu, Y., Efferth, T., \& Fu, Y. (2013). Dihydroquercetin (DHQ) induced HO-1 and NQO1 expression against oxidative stress through the Nrf2dependent antioxidant pathway. Journal of Agricultural and Food Chemistry, 61(11), 2755-2761. https://doi.org/10.1021/jf304768p

35. Islam, J., Shree, A., Vafa, A., Afzal, S. M., \& Sultana, S. (2021). Taxifolin ameliorates benzo[a]pyrene-induced lung injury possibly via stimulating the $\mathrm{Nrf} 2$ signalling pathway. International Immunopharmacology, 96, 107566. https://doi.org/10.1016/j. intimp.2021.107566

36. Wang, W., Ma, B. L., Xu, C. G., \& Zhou, X. J. (2020). Dihydroquercetin protects against renal fibrosis by activating the Nrf2 pathway. Phytomedicine, 69, 153185. https://doi.org/10.1016/j. phymed.2020.153185

37. Chan, K., \& Kan, Y. W. (1999). Nrf2 is essential for protection against acute pulmonary injury in mice. Proceedings of the National Academy of Sciences of the United States of America, 96(22), 12731-12736. https://doi.org/10.1073/pnas.96.22.12731

38. Shindo, Y., \& Hashimoto, T. (1997). Time course of changes in antioxidant enzymes in human skin fibroblasts after UVA irradiation. Journal of Dermatological Science, 14(3), 225-232. https:// doi.org/10.1016/s0923-1811(96)00578-6

39. RajnochováSvobodová, A., Galandáková, A., Šianská, J., Doležal, D., Ulrichová, J., \& Vostálová, J. (2011). Acute exposure to solar simulated ultraviolet radiation affects oxidative stress-related biomarkers in skin, liver and blood of hairless mice. Biological and Pharmaceutical Bulletin, 34(4), 471-479. https://doi.org/10.1248/ bpb.34.471

40. Rice-Evans, C. A., \& Miller, N. J. (1996). Antioxidant activities of flavonoids as bioactive components of food. Biochemical Society Transactions, 24(3), 790-795. https://doi.org/10.1042/bst0240790

41. Gažák, R., Svobodová, A., Psotová, J., Sedmera, P., Přikrylová, V., Walterová, D., \& Křen, V. (2004). Oxidised derivatives of silybin and their antiradical and antioxidant activity. Bioorganic \& Medicinal Chemistry, 12(21), 5677-5687. https://doi.org/10. 1016/j.bmc.2004.07.064

42. Osorio, E., Pérez, E. G., Areche, C., Ruiz, L. M., Cassels, B. K., Flórez, E., \& Tiznado, W. (2013). Why is quercetin a better antioxidant than taxifolin? Theoretical study of mechanisms involving activated forms. Journal of Molecular Modeling, 19(5), 2165-2172. https://doi.org/10.1007/s00894-012-1732-5

43. Metodiewa, D., Jaiswal, A. K., Cenas, N., Dickancaité, E., \& Segura-Aguilar, J. (1999). Quercetin may act as a cytotoxic prooxidant after its metabolic activation to semiquinone and quinoidal product. Free Radical Biology and Medicine, 26(1-2), 107-116. https://doi.org/10.1016/s0891-5849(98)00167-1

44. Boots, A. W., Kubben, N., Haenen, G. R., \& Bast, A. (2003). Oxidized quercetin reacts with thiols rather than with ascorbate: Implication for quercetin supplementation. Biochemical and Biophysical Research Communications, 308(3), 560-565. https://doi. org/10.1016/s0006-291x(03)01438-4

45. Li, C., Zhang, W. J., Choi, J., \& Frei, B. (2016). Quercetin affects glutathione levels and redox ratio in human aortic endothelial cells not through oxidation but formation and cellular export of quercetin-glutathione conjugates and upregulation of glutamate-cysteine ligase. Redox Biology, 9, 220-228. https://doi.org/10.1016/j.redox. 2016.08.012

46. Boots, A. W., Li, H., Schins, R. P., Duffin, R., Heemskerk, J. W., Bast, A., \& Haenen, G. R. (2007). The quercetin paradox. Toxicology and Applied Pharmacology, 222(1), 89-96. https://doi.org/10. 1016/j.taap.2007.04.004

47. Vásquez-Espinal, A., Yañez, O., Osorio, E., Areche, C., GarcíaBeltrán, O., Ruiz, L. M., Cassels, B. K., \& Tiznado, W. (2019). Theoretical study of the antioxidant activity of quercetin oxidation products. Frontiers in Chemistry, 27, 818. https://doi.org/10.3389/ fchem. 2019.00818 
48. Kosina, P., Paloncýová, M., Rajnochová Svobodová, A., Zálešák, B., Biedermann, D., Ulrichová, J., \& Vostálová, J. (2018). Dermal delivery of selected polyphenols from Silybum marianum. Theoretical and experimental study. Molecules, 24(1), 61. https://doi. org/10.3390/molecules24010061

49. Filipe, P., Silva, J. N., Haigle, J., Freitas, J. P., Fernandes, A., Santus, R., \& Morlière, P. (2005). Contrasting action of flavonoids on phototoxic effects induced in human skin fibroblasts by UVA alone or UVA plus cyamemazine, a phototoxic neuroleptic. Photochemical \& Photobiological Sciences, 4(5), 420-428. https:// doi.org/10.1039/b416811a

50. Tian, R., Yang, Z., Lu, N., \& Peng, Y. Y. (2019). Quercetin, but not rutin, attenuated hydrogen peroxide-induced cell damage via heme oxygenase-1 induction in endothelial cells. Archives of Biochemistry and Biophysics, 676, 108157. https://doi.org/10.1016/j. abb.2019.108157

\section{Authors and Affiliations}

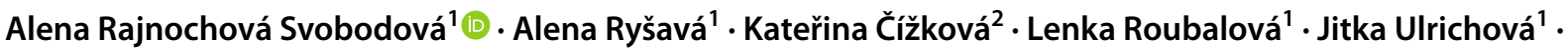 Jiří Vrba ${ }^{1}$. Bohumil Zálešák ${ }^{3}$. Jitka Vostálová ${ }^{1}$ (i)}

1 Department of Medical Chemistry and Biochemistry, Faculty of Medicine and Dentistry, Palacký University, Hněvotínská 3, 77515 Olomouc, Czech Republic

2 Department of Histology and Embryology, Faculty of Medicine and Dentistry, Palacký University, Hněvotínská 3, 77900 Olomouc, Czech Republic
3 Department of Plastic and Aesthetic Surgery, University Hospital Olomouc, I. P. Pavlova 6, 77900 Olomouc, Czech Republic 